\title{
Reprogramming of human pancreatic exocrine cells to $\beta$-like cells
}

\author{
M Lemper ${ }^{1}$, G Leuckx ${ }^{1}$, Y Heremans $^{1}$, MS German ${ }^{2}$, H Heimberg ${ }^{1}$, L Bouwens ${ }^{1,3}$ and L Baeyens ${ }^{\star, 1,2,3}$
}

Rodent acinar cells exhibit a remarkable plasticity as they can transdifferentiate to duct-, hepatocyte- and islet $\beta$-like cells. We evaluated whether exocrine cells from adult human pancreas can similarly respond to proendocrine stimuli. Exocrine cells from adult human pancreas were transduced directly with lentiviruses expressing activated MAPK (mitogen-activated protein kinase) and STAT3 (signal transducer and activator of transcription 3) and cultured as monolayers or as 3D structures. Expression of STAT3 and MAPK in human exocrine cells activated expression of the proendocrine factor neurogenin 3 in $50 \%$ to $80 \%$ of transduced exocrine cells. However, the number of insulin-positive cells increased only in the exocrine cells grown initially in suspension before 3D culture. Lineage tracing identified human acinar cells as the source of Ngn3- and insulin-expressing cells. Long-term engraftment into immunocompromised mice increased the efficiency of reprogramming to insulin-positive cells. Our data demonstrate that exocrine cells from human pancreas can be reprogrammed to transplantable insulin-producing cells that acquire functionality. Given the large number of exocrine cells in a donor pancreas, this approach presents a novel strategy to expand cell therapy in type 1 diabetes.

Cell Death and Differentiation (2015) 22, 1117-1130; doi:10.1038/cdd.2014.193; published online 5 December 2014

To overcome the scarcity of endocrine $\beta$ cells for cell replacement therapy in patients with type 1 diabetes, additional sources of transplantable $\beta$ cells are needed. Reprogramming of non-endocrine pancreatic cells into $\beta$ cells offers one attractive approach. Exocrine cells comprise the vast majority of cells obtained from cadaveric donor pancreases, but are discarded following isolation of the endocrine islets, and thus could provide a large pool of cells for conversion to $\beta$ cells.

Historically pancreatic duct cells have been favored as the potential source of new islet $\beta$ cells owing to histological observations in the developing and adult human pancreas showing close association of duct and endocrine cells, ${ }^{1,2}$ with cells detected expressing both duct and $\beta$-cell markers. Purification of human duct cells based on CA19.9 expression and subsequent $3 \mathrm{D}$ in vitro culture was shown to yield a limited number of insulin ${ }^{+}$cells with an immature glucose-induced insulin response. ${ }^{3,4}$ These reports have been contested later on suggesting that dedifferentiated islet $\beta$ cells may have been the source of these new insulin ${ }^{+}$cells, ${ }^{5}$ leaving the differentiation potential of human exocrine duct cells currently unanswered.

Pancreatic acinar cells represent an alternative attractive population for exocrine-to-endocrine transdifferentiation owing to their abundance and potential for plasticity. Rodent pancreatic acinar cells are shown to exhibit phenotypic instability in vitro and undergo a spontaneous ductal metaplasia following isolation. ${ }^{6,7}$ These metaplastic acinar cells can adopt a duct-,${ }^{6,8}$ hepatocyte- ${ }^{9}$ and $\beta$-like phenotype,,${ }^{8,10-12}$ depending on the stimuli provided. In contrast, similar plasticity has not been demonstrated for human pancreatic acinar cells, although they can undergo spontaneous metaplasia to duct-like cells in vitro ${ }^{3}$ similar to what is observed in rodents. We previously showed that supplementation of the medium of cultured rat acinar cells with EGF and LIF,10,14 and triggering MAPK (mitogen-activated protein kinase) and STAT3 (signal transducer and activator of transcription 3) signal transduction ${ }^{14}$ converts them to $\beta$-like cells. Therefore, we hypothesized that ectopic signaling through MAPK and STAT3 might convert human acinar cells to $\beta$-like cells as well. The current study shows that ectopic expression of activated MAPK and STAT3 in human pancreatic acinar cells activates the proendocrine transcription factor neurogenin 3 (Neurog3) and reprograms human acinar cells to insulin-positive $\beta$-like cells able to ameliorate chemical diabetes.

\section{Results}

Overexpression of MAPK ${ }^{\mathrm{CA}}$ and STAT3 ${ }^{\mathrm{CA}}$ activates an endocrine differentiation program in monolayers of cultured exocrine cells. Pancreatic cell populations consisting of acinar, centroacinar, duct and few endocrine/ mesenchymal cells from human donor pancreata were transduced with LeMS ${ }^{\mathrm{CA}}$, a bicistronic lentivirus constitutively overexpressing active MAPK and STAT3, and subsequently

\footnotetext{
${ }^{1}$ Diabetes Research Center, Vrije Universiteit Brussel, Laarbeeklaan 103, 1090 Brussels, Belgium and ${ }^{2}$ Diabetes Center, Eli and Edythe Broad Center for Regenerative Medicine and Stem Cell Research, University of California San Francisco, San Francisco, CA 94143-0669, USA

${ }^{*}$ Corresponding author: L Baeyens, Diabetes Center, Eli and Edythe Broad Center for Regenerative Medicine and Stem Cell Research, University of California San Francisco, San Francisco, CA 94143-0669, USA. Tel: +1 415476 1030; Fax: +1 415514 2346; E-mail: Ibaeyens@ diabetes.ucsf.edu or Ibaeyens@ vub.ac.be

${ }^{3}$ Senior authors.

Abbreviations: KRT19, cytokeratin 19; Gcg, glucagon; IHC, immunohistochemistry; INS, insulin; PTF1A, pancreas-specific transcription factor 1a; PDX1, pancreatic and duodenal homeobox 1; NEUROG3, neurogenin 3; MAPK, mitogen-activated protein kinase; STAT3, signal transducer and activator of transcription 3; GFP, green fluorescent protein; Cela2A, chymotrypsin-like elastase $2 \mathrm{~A}$

Received 29.6.14; revised 04.9.14; accepted 23.10.14; Edited by M Federici; published online 05.12.14
} 
cultured as adherent monolayers (Figure 1a). In the LeMS ${ }^{\mathrm{CA}}$ infected cell cultures, the levels of NEUROG3, PAX4 and $N K X 2.2$, mRNAs encoding transcription factors functioning in endocrine progenitor cells, were increased compared with control-transduced cells (LeGFP) (Figure 2a, protocol 1). NKX6.1 mRNA, however, significantly decreased and INS (insulin) mRNA remained similar to control. At a transduction efficiency of $48.1 \pm 2.1 \%(n=4)$, Ngn3 protein was detected in $38.3 \pm 1.4 \%(n=4)$ of total exocrine cells (Figure $2 \mathrm{~d})$. A small fraction of the $\mathrm{Ngn}^{+}$cells coexpressed Pdx1 (pancreatic and duodenal homeobox 1$)$ protein $(7.6 \pm 0.8 \% ; n=4)$, but insulin $^{+}$cells were not increased (Figure 2e). All Ngn3 ${ }^{+}$and $\mathrm{Pdx}^{+}$cells analyzed coexpressed GFP (green fluorescent protein), indicating the presence of LeMS ${ }^{\mathrm{CA}}$ virus. In control LeGFP-transduced cells, no Ngn3 or Pdx1 expression was detected (Supplementary Figures S1A and B).
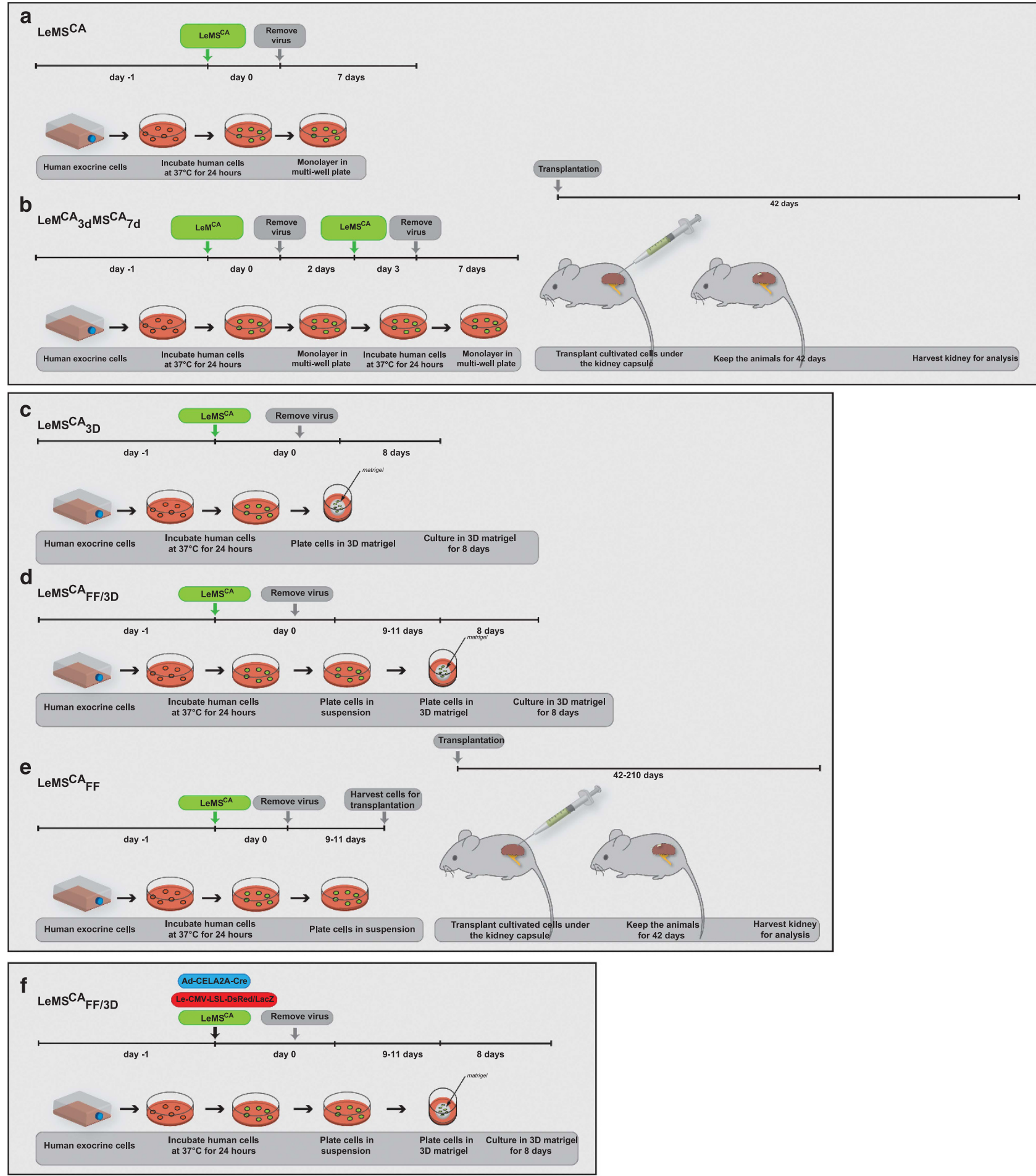
LeMS $^{\mathrm{CA}}$-transduced cells also contained higher levels of mRNA encoding acinar cell-specific markers relative to LeGFP-transduced cells (Figure 2b, protocol 1), despite similar marked decreases in phenotypically stable acinar cells in both cultures (Supplementary Figure S1C). In LeMS ${ }^{\mathrm{CA}}$ cells, the levels of ductal mRNAs FOXA2 and SOX9 were significantly decreased (Figure 2c, protocol 1), whereas the expression of ONECUT1, a previously described regulator of Neurog3 expression in rodents, ${ }^{15}$ was increased (Figure $2 \mathrm{c}$, protocol 1). All cells, independent of their state of transduction, expressed the duct markers Krt19 (cytokeratin 19) and Sox9 by immunostaining, but no acinar cell-specific proteins (Supplementary Figure S1D).

In an attempt to increase endocrine differentiation, we examined the effect of overexpressing either MAPK ${ }^{C A}\left(M^{C A}\right)$ or STAT3 ${ }^{\mathrm{CA}}\left(\mathrm{S}^{\mathrm{CA}}\right)$ alone before the combination of $\mathrm{MAPK}^{\mathrm{CA}}+\mathrm{STAT3}^{\mathrm{CA}}\left(\mathrm{MS}^{\mathrm{CA}}\right)$. Three days of STAT3 ${ }^{\mathrm{CA}}$ followed by 7 days of $\mathrm{MS}^{\mathrm{CA}}\left(\operatorname{LeS}^{\mathrm{CA}}{ }_{3 \mathrm{~d}} \mathrm{MS}^{\mathrm{CA}}{ }_{7 \mathrm{~d}}\right)$ did not further increase Ngn3 expression and lowered $\mathrm{Pd} \mathrm{d} 1$ expression as compared with LeMS ${ }^{C A}$ only (Supplementary Figure S2A). However, overexpression of MAPK ${ }^{\mathrm{CA}}$ before $\mathrm{MS}^{\mathrm{CA}}\left(\mathrm{LeM}^{\mathrm{CA}}{ }_{3 \mathrm{~d}} \mathrm{MS}^{\mathrm{CA}}{ }_{7 \mathrm{~d}}\right)$ markedly increased endocrine gene expression (Figures $1 \mathrm{~b}$ and $2 \mathrm{a}$, protocol 2). Compared with LeMS ${ }^{\mathrm{CA}}$ cells (Figure $2 \mathrm{a}$, protocols 1 and 2), the amount of NKX6.1, PDX1 and INS mRNA significantly increased in LeM ${ }^{C A}{ }_{3 d} M S^{C A}{ }_{7 d}$ suggestive of the ongoing $\beta$-cell differentiation $(n=9 ; P<0.01)$. Although the number of $\mathrm{Ngn3}^{+}$cells remained similar $(39.9 \pm 2.4 \%$ versus $38.3 \pm 1.4 \%$ in LeMS $^{C A}$ cells) (Figures $1 \mathrm{~d}-\mathrm{f}$ ), the number of $\mathrm{LeM}^{\mathrm{CA}}{ }_{3 \mathrm{~d}} \mathrm{MS}^{\mathrm{CA}}{ }_{7 \mathrm{~d}}$ cells with $\mathrm{Pdx} 1$ protein was increased $\left(28.0 \pm 2.5 \%\right.$ versus $7.6 \pm 0.8 \%$ LeMS $^{\mathrm{CA}}$ cells; Figures $2 \mathrm{e}$ and $\mathrm{f}$ ), indicating that pre-treatment with MAPK ${ }^{\mathrm{CA}}$ did not hamper the activation of a proendocrine program. However, despite the presence of high endogenous Pdx1, the number of hormone-producing cells did not increase (Figure 2d).

The expression level of acinar cell-specific mRNAs was comparable in LeMS ${ }^{C A}$ and $\operatorname{LeM}^{C A}{ }_{3 d} M^{C A}{ }_{7 d}$ cells (Figure $2 b$ ). The expression of ONECUT1 mRNA was markedly increased in $\mathrm{LeM}^{\mathrm{CA}}{ }_{3 \mathrm{~d}} \mathrm{MS}^{\mathrm{CA}}{ }_{7 \mathrm{~d}}$ cells, whereas FOXA2 transcripts significantly decreased. The majority of $\mathrm{Pdx} 1^{+}$cells still displayed a duct-like phenotype, expressing Krt19 and Sox9, the latter at low levels (Supplementary Figure S2B).

Ectopic expression of MAPK ${ }^{\mathrm{CA}}$ and STAT3 ${ }^{\mathrm{CA}}$ thus demonstrates the potential of human exocrine cells to respond to this specific signaling by initiating a proendocrine differentiation program, similar to what has been described previously in rodent cells, ${ }^{8,10,14}$ albeit without the ability to complete endocrine differentiation under these conditions.

Transplantation of human exocrine cells overexpressing $\mathrm{MS}^{\mathrm{CA}}$ allows for further endocrine differentiation of 2D exocrine cell cultures. As endocrine progenitor cells have already been shown to mature in vivo to functional $\beta$ cells, ${ }^{16}$ we evaluated the capacity of an in vivo environment to provide critical maturation signals missing in vitro. Following monolayer culture, LeM ${ }_{3 \mathrm{~d}} \mathrm{MS}^{\mathrm{CA}}{ }_{7 \mathrm{~d}}$ or LeGFP cells were transplanted under the kidney capsule of immunocompromised mice to study their potential for maturation to endocrine cells (Figure 1b). When harvested 42 days after engraftment, very few Neurog $3^{+}$cells remained (Figures $3 a$ and $\mathrm{d})$, whereas the number of $\mathrm{Pdx} 1^{+}$cells persisted $(n=5)$ and $\mathrm{Krt}^{+} \mathrm{9}^{+}$cells marginally decreased $(84.3 \pm 2.6 \%$ versus $92.7 \pm 0.8 \%$ before transplantation) (Figure $3 d$ ). The LeM $^{\mathrm{CA}}{ }_{3 \mathrm{~d}} \mathrm{MS}^{\mathrm{CA}}{ }_{7 \mathrm{~d}}$ grafts contained both glucagon ${ }^{+}$ (Figure $3 b$ ) cells and insulin ${ }^{+}$cells (Figure $3 c$ ) but the LeGFP grafts did not. The number of insulin ${ }^{+}$cells significantly increased following engraftment $(0.44 \pm 0.06 \%$ before versus $1.17 \pm 0.20 \%$ after transplantation; $P<0.05$ ) (Figures $3 \mathrm{c}$ and d), whereas no insulin ${ }^{+}$cells were observed among grafted LeGFP cells. The insulin ${ }^{+}$cells did not stain for Krt19 but only a few displayed nuclear MafA, indicative of incomplete maturation to functional $\beta$ cells. ${ }^{17,18}$ Rare insulin ${ }^{-}$Maf $^{+}{ }^{+}$cells were observed. Taken together, these observations resemble the transient expression of Ngn3 during pancreas development and support the hypothesis that engraftment of $\mathrm{LeM}^{\mathrm{CA}}{ }_{3 \mathrm{~d}} \mathrm{MS}^{\mathrm{CA}}{ }_{7 d}$ exocrine cells from human pancreas further stimulates endocrine differentiation.

Overexpression of $\mathrm{MS}^{\mathrm{CA}}$ promotes endocrine differentiation in human exocrine 3D cultures. In an attempt to reproduce the endocrine cell differentiation observed in vivo in cultured cells and knowing that exocrine $\operatorname{LeM}^{\mathrm{CA}}{ }_{3 \mathrm{~d}} \mathrm{MS}^{\mathrm{CA}}{ }_{7 \mathrm{~d}}$ cells in 2D culture did not differentiate efficiently, we cultured the cells in 3D matrix for 8 days (LeMS ${ }_{3 D}$ ) (Figure $1 \mathrm{c}$ ), which promotes alterations in cell polarity and cell-cell contact that stimulate differentiation. ${ }^{19-21}$ Because suspension culture of rodent acinar cells allows their dedifferentiation (rather than transdifferentiation to duct-like cells) and subsequent differentiation to insulin ${ }^{+}$cells, ${ }^{8,22}$ we examined the effects of suspension preculture by keeping freshly

Figure 1 Schematic overviews of different culture systems. (a and $\mathbf{b}$ ) Schematic overview of the monolayer culture system. (a) Transduction of human exocrine cells obtained from cadaveric donors with a lentivirus overexpressing activated MAPK and STAT3 (LeMS ${ }^{\mathrm{CA}}$ ) and subsequent formation of adherent monolayer cultures. The cells are exposed to $\mathrm{LeMS}^{\mathrm{CA}}$ for $24 \mathrm{~h}$ after which the excess virus is washed away. The cells are kept for 7 days in multiwall plates to allow monolayer formation. (b) Overexpression of MAPK ${ }^{\mathrm{CA}}$ for 3 days before combined overexpression of MAPK ${ }^{\mathrm{CA}}-\mathrm{STAT}^{\mathrm{CA}}\left(\mathrm{LeM}^{\mathrm{CA}}{ }_{3 \mathrm{~d}} \mathrm{MS}^{\mathrm{CA}}{ }_{7 \mathrm{~d}}\right)$. The cells are exposed to Le-MAPK ${ }^{\mathrm{CA}}$ for $24 \mathrm{~h}$, followed by removal of the excess virus, and cells are kept in fresh medium for 2 more days. On the third day, the cells are transduced with Le-MAPK ${ }^{\mathrm{CA}}$-STAT3 ${ }^{\mathrm{CA}}$. The medium is changed after $24 \mathrm{~h}$ and the cells ate kept in multiwall plates with fresh medium for 7 days. To allow for potential further differentiation, the LeM ${ }_{3{ }^{C A} M S^{C A}}{ }_{7 d}$ condition is transplanted under the kidney capsule of immunodeficient mice. The animals are kept for 42 days after which the graft-bearing kidney is removed and the graft is recovered for further analysis. (c-e) Schematic overview of the 3D, FF/3D and FF/in vivo culture systems. (c) Transduction of human exocrine cells with a lentivirus overexpressing activated MAPK and STAT3 and subsequent 3D Matrigel culture (LeMS $\left.{ }^{\mathrm{CA}}{ }_{3 \mathrm{D}}\right)$. The cells are exposed to LeMS ${ }^{\mathrm{CA}}$ for $24 \mathrm{~h}$ followed by removal of the excess virus. The cells are kept in $3 \mathrm{D}$ Matrigel for 8 days. (d) Transduction of human exocrine cells with a lentivirus overexpressing activated MAPK and STAT3 and subsequent free-floating/3D Matrigel culture (LeMS $\left.{ }^{\mathrm{CA}} \mathrm{FF} / 3 \mathrm{D}\right)$. The cells are exposed to LeMS $^{\mathrm{CA}}$ for $24 \mathrm{~h}$ followed by removal of the excess virus. The cells are kept in free-floating culture for $\sim 10$ days after which they are transferred to 3D Matrigel for 8 days. (e) The free-floating cells (LeMS ${ }^{\mathrm{CA}} \mathrm{FF}$ ) are transplanted under the kidney capsule of immunodeficient mice to allow potential further differentiation. The animals are kept for 42 days after which the graft-bearing kidney is removed and the graft is recovered for further analysis. (f) Schematic overview of the acinar-specific genetic lineage tracing experiment. The human exocrine cells are exposed to the three viruses (Ad-Ela-Cre, Le-CMV-LSL-DsRed, LeMS ${ }^{C A}$ ) at the same time for $24 \mathrm{~h}$ after which the excess virus is removed. The cells are then kept in free-floating culture for $\sim 10$ days after which they are transferred to 3D Matrigel for 8 days 
a

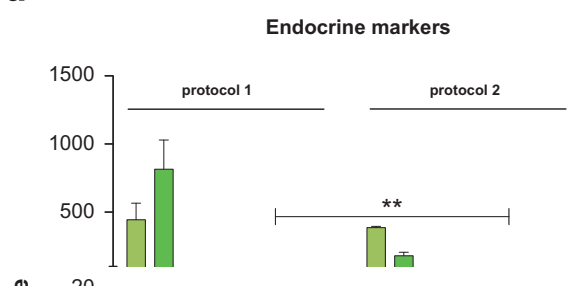

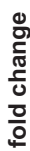

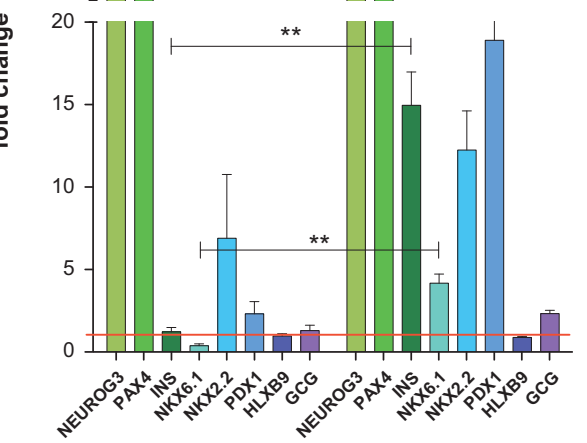

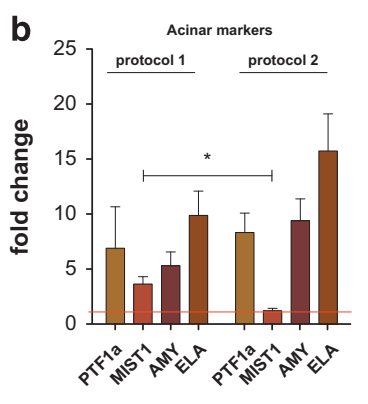

C

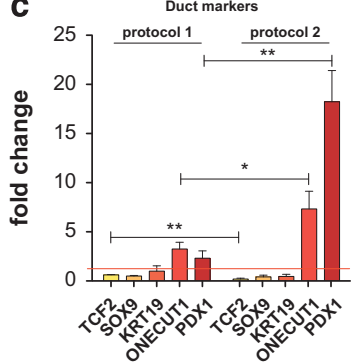

DNA Neurog 3 Ins

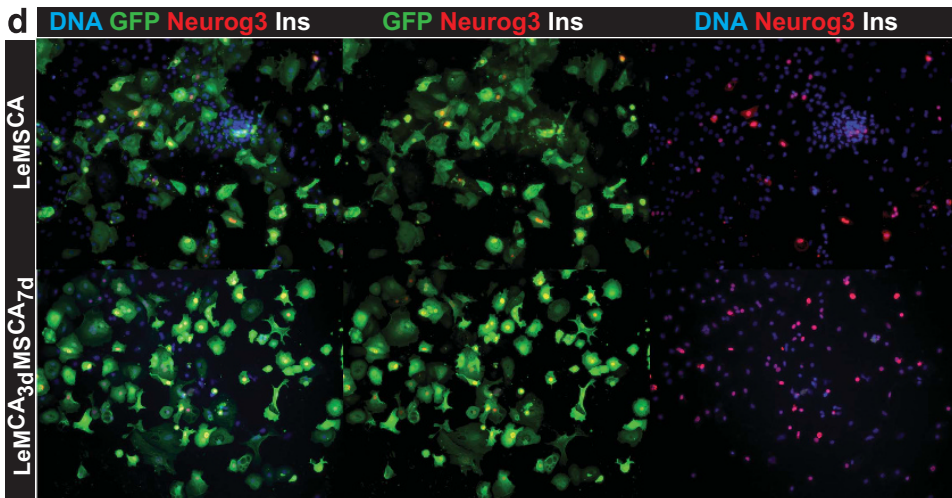

e DNA GFP Pdx1 Neurog3 GFP Pdx1 Neurog3
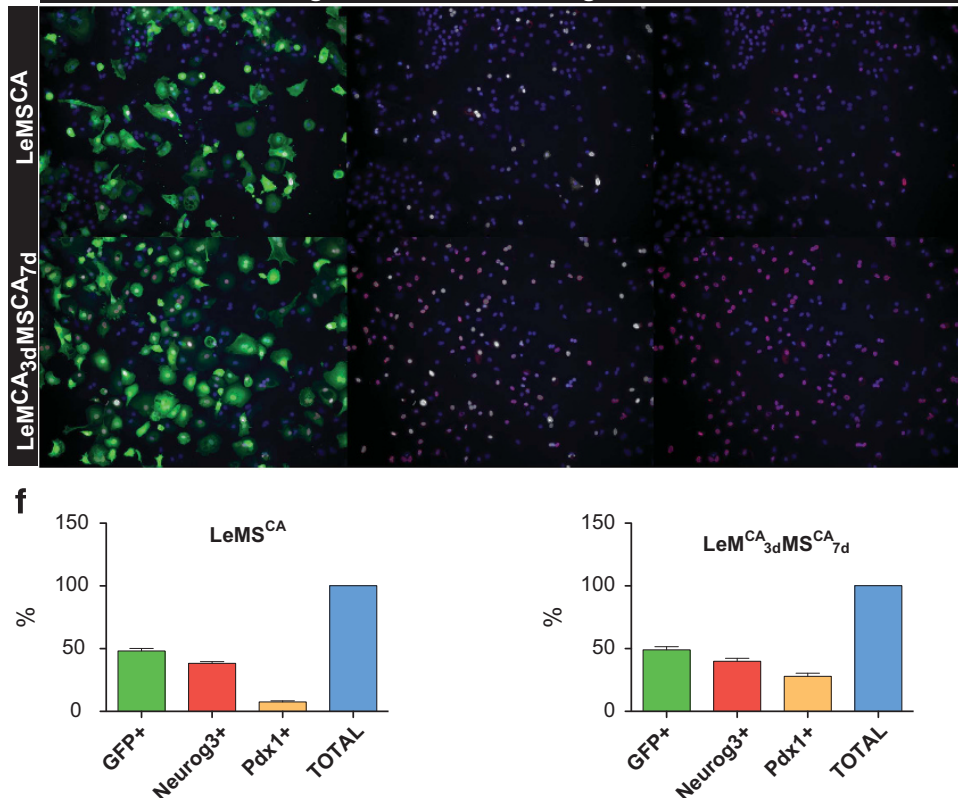
isolated, lentivirus-transduced exocrine cells in free-floating suspension culture for 10 days followed by 3D matrix culture for 8 days (LeMS $\left.{ }^{\mathrm{CA}}{ }_{\mathrm{FF} / 3 \mathrm{D}}\right)$ (Figure $1 \mathrm{~d}$ ).

LeMS $_{3 D}{ }_{3 D}$ and LeMS ${ }_{F F / 3 D}$ cells contained significantly more NEUROG3 and NEUROD1 mRNA compared with LeGFP $_{3 D}$ cells, whereas the level of PDX1 and INS transcripts remained similar (Figure 4a). Compared with LeGFP FF/3D, $_{\text {, }}$ LeMS $^{\mathrm{CA}}{ }_{\mathrm{FF} / 3 \mathrm{D}}$ cells contained significantly more NKX6.1, NEUROD1 and ISL1 transcripts $(P<0.05)$. A significant increase in NEUROD1 expression was already observed in the LeMS ${ }_{3 \mathrm{D}}^{\mathrm{A}}$ culture condition; however, this increase is even more pronounced in $\mathrm{LeMS}_{\mathrm{FF} / 3 \mathrm{D}}^{\mathrm{CA}}$, suggesting improved endocrine differentiation, a conclusion supported by increased abundance of insulin transcripts and protein when a freefloating culture period was included (Figures $4 \mathrm{a}$ and e).

Compared with LeGFP control cells, the levels of duct cellspecific transcripts did not change (Figure 4b). All cells expressed Krt19 at the protein level (Figures 4c and e). The acinar cell-specific transcript PTF1A (pancreas-specific transcription factor 1a) increased in LeMS ${ }^{\mathrm{CA}}$ cells (Figure $4 \mathrm{~b}$ ) without an associated rise in the mRNA encoding acinar cellspecific proteins amylase, chymotrypsin, Mist1 and Ptf1a.

Neurog $3^{+}$cells were detected in $\operatorname{LeMS}^{\mathrm{CA}}{ }_{3 \mathrm{D}}(4.6 \pm 1.3 \%)$ and LeMS $^{\mathrm{CA}}{ }_{\mathrm{FF} / 3 \mathrm{D}}(7.7 \pm 3.0 \%)$ but not in LeGFP $_{3 \mathrm{D}}$ or LeGFP $P_{F F / 3 D}$ cultures (Figures $4 \mathrm{c}$ and $d$ ). The number of $\mathrm{Pdx}^{+}$cells was significantly increased in both LeMS $_{3 \mathrm{DA}}$ $(10.7 \pm 2.0 \%, P<0.01)$ and LeMS $^{\mathrm{CA}}{ }_{\mathrm{FF} / 3 \mathrm{D}}$ cells $(6.1 \pm 2.6 \%$, $P<0.05$ ) as compared with LeGFP control cells (Figures $4 d$ and f); and insulin ${ }^{+}$cells were even more markedly increased in LeMS ${ }_{\mathrm{FF} / 3 \mathrm{D}}$ cells $(7.3 \pm 2.6 \%(n=7))$ versus LeMS $_{3 \mathrm{DA}}$ $(0.83 \pm 0.40 \%$ in $(n=8))$ and LeGFP FF/3D $(0.06 \pm 0.06 \%$ $(n=10) ; P<0.05)$ (Figures $4 \mathrm{~d}$ and $\mathrm{f}$ ).

KRT19, PTF1A and NEUROG3 mRNA levels were confirmed by conventional reverse transcription-PCR and indicate that the acinar cells do adopt a duct-like phenotype during culture (Supplementary Figure S3), as previously reported, ${ }^{13,23}$ and that at least a sub-population of $\mathrm{LeMS}^{\mathrm{CA}}{ }_{\mathrm{FF} / 3 \mathrm{D}}$ cells initiate an endocrine differentiation program (Supplementary Figure S3). Unlike the pre-existing $\beta$ cells, the insulin ${ }^{+}$LeMS $^{\mathrm{CA}}{ }_{\mathrm{FF} / 3 \mathrm{D}}$ cells did not stain for MafA by immunohistochemistry (IHC), suggesting that the newly formed insulin ${ }^{+}$cells are not fully mature (Supplementary Figure S4A). The new insulin ${ }^{+}$cells did not derive by proliferation of pre-existing $\beta$ cells: no insulin ${ }^{+}$cells expressed the proliferation marker Ki67 (Supplementary Figure S5).

Unlike the exocrine cell cultures, transduction of human islets with LeMS ${ }^{\mathrm{CA}}$ did not activate the expression of Neurog3
(Supplementary Figure S4). In addition, both transduced $\left(\mathrm{GFP}^{+}\right)$and non-transduced $\left(\mathrm{GFP}^{-}\right) \beta$ cells expressed MafA, $\mathrm{Pdx} 1$ and insulin, showing that viral transduction does not prevent their expression.

Short-term transplantation of LeMS ${ }^{\mathrm{CA}}$ FF cells promotes
endocrine differentiation. Because the LeMS transduced human exocrine cells yielded the most efficient endocrine differentiation, we tested whether substituting 3D culture by engraftment could further improve the efficiency of differentiation. LeMS ${ }^{\mathrm{CA}}$ FF or LeGFP ${ }_{\mathrm{FF}}$ cells were transplanted under the kidney capsule of immunocompromised mice and 42 days later the graft-bearing kidney was harvested for analysis (Figure 1e). The amount of $\mathrm{GFP}^{+}{ }^{+}$Tnsulin $^{+}$cells strongly increased in LeMS ${ }^{\mathrm{CA}} \mathrm{FF}$ grafts compared with LeGFP $_{\mathrm{FF}}$ controls (Figures $5 \mathrm{a}$ and $\mathrm{d}$ ). The grafts showed a near total loss of $\mathrm{Ngn}^{+}$cells, while Pdx1 was present in all human cells (Figures $5 \mathrm{~b}$ and $\mathrm{d}$ ). A markedly higher expression of $\mathrm{Pdx} 1$ was observed in $4.2 \pm 0.7 \%$ cells of LeMS ${ }^{\mathrm{CA}}$ FF grafts $\left(\mathrm{Pdx} 1^{\text {high }}\right.$ cells), a significant increase $(P<0.001 ; n=5)$ compared with control grafts and concordant with transplanted LeMS ${ }^{\mathrm{CA}}$ cells after $2 \mathrm{D}$ culture. The majority of the grafted cells are $\mathrm{Krt19}^{+}$, except for the hormone $^{+}$cells (Figures $5 \mathrm{a}$ and $\mathrm{c}$ ). The fraction of insulin ${ }^{+}$ cells increased significantly $\left(5.6 \pm 1.1 \%\right.$ in LeMS ${ }^{\mathrm{CA}}$ FF versus $0.5 \pm 0.3 \%$ in LeGFP FFF $;<0.001, n=10$ ) (Figure $5 \mathrm{~d}$ ) and was similar to that obtained in LeMS ${ }^{\mathrm{CA}}{ }_{\mathrm{FF} / 3 \mathrm{D}}$ cells in vitro (Figure $4 \mathrm{e}$ ). In absolute numbers, however, the yield of insulin $^{+}$cells remained rather low.

New human $\boldsymbol{\beta}$ cells derived from reprogrammed acinar cells. For unbiased tracing of the fate of the insulin ${ }^{+}$ LeMS $^{\mathrm{CA}}{ }_{\mathrm{FF} / 3 \mathrm{D}}$ cells, a lentivirus-mediated, Cre-lox-based reporter expression was used. First, infection with $\mathrm{AdCe}$ la2 $A^{\text {Cre }}$ virus ensured acinar-specific expression of Cre recombinase under the control of the elastase $2 \mathrm{~A}$ gene promoter. When combined with a second virus that, upon Cre-mediated excision of the loxSTOPlox (LSL) signal, constitutively expressed a DsRed reporter under the control of the cytomegalovirus promoter (LeCMV-LSL-DsRed), acinar cells could be permanently traced (Figure 1f). The fate of acinar cells from human pancreas was traced in LeMS ${ }^{\mathrm{CA}}{ }_{\mathrm{FF} / 3 \mathrm{D}}$ cells as these showed the most efficient endocrine differentiation. The analysis was performed on cells coexpressing the lineage tracer DsRed and the LeGFP- or LeMS ${ }^{C A}$-derived GFP (Figure $6 a)$. Insulin ${ }^{+}$DsRed $^{+}\left(20.8 \pm 1.4 \%\right.$ of all insulin ${ }^{+}$ cells; $n=4)$ or $\mathrm{Neurog}^{+} \mathrm{DsRed}^{+}\left(16.3 \pm 1.1 \%\right.$ of all $\mathrm{Ngn}^{+}$

Figure 2 Overexpression of MAPK ${ }^{\mathrm{CA}}$ and STAT3 ${ }^{\mathrm{CA}}$ promotes endocrine differentiation in vitro. (a and c) Gene expression profile of endocrine markers (a), acinar markers (b) and ductal markers (c). LeMS conditions are normalized to control conditions (LeGFP) set at 1 (red line). Protocol 1: Original protocol with 7-day combined STAT3 $3^{\mathrm{CA}} / \mathrm{MAPK}^{\mathrm{CA}}$ $\left(\right.$ LeMS $\left.^{\mathrm{CA}}\right)\left(n=6 ;{ }^{*} P<0.05 ;{ }^{*} P<0.01\right)$. Protocol 2: Sequential treatment with 3-day MAPK ${ }^{\mathrm{CA}}$ followed by 7-day combined STAT3 ${ }^{\mathrm{CA}} / \mathrm{MAPK}^{\mathrm{CA}}\left(\mathrm{LeMM}^{\mathrm{CA}}{ }_{3 \mathrm{~d}} \mathrm{MS}^{\mathrm{CA}}{ }_{7 \mathrm{~d}}\right)(n=9$; ${ }^{\star} P<0.05 ;{ }^{\star} P<0.01$ ). Endocrine genes INS, PDX1 and NKX6.1 are significantly upregulated in protocol 2 , whereas exocrine genes MIST1 and FOXA2 were downregulated compared with protocol 1. The trend on endocrine genes combined with the increase in ONECUT1 transcripts suggests an accelerated endocrine differentiation in protocol 2. (d) Immunocytochemical analysis of Neurog3 and insulin expression after the original 7-day protocol (LeMS ${ }^{\mathrm{CA}}$ ) and the sequential 3-day MAPK ${ }^{\mathrm{CA}}$ followed by 7-day combined $\mathrm{STAT}^{\mathrm{CA}} / \mathrm{MAPK}^{\mathrm{CA}}\left(\mathrm{LeM}^{\mathrm{CA}}{ }_{3 \mathrm{~d}} \mathrm{MS}^{\mathrm{CA}}{ }_{7 \mathrm{dd}}\right.$ ). Neurog $3^{+}$cells were readily detected in LeMS ${ }^{\mathrm{CA}}$ and the fraction of Ngn3-expressing cells slightly increased in LeM ${ }_{3 \mathrm{dd}} \mathrm{MS}^{\mathrm{CA}}{ }_{7 \mathrm{~d}}$. No insulin ${ }^{+}$ cells could be detected in LeMS ${ }^{C A}$ or LeM ${ }^{C A}{ }_{3 d} M S^{C A}{ }_{7 d}$. (e) Immunocytochemical analysis of Pdx1 and Neurog3 after LeMS ${ }^{C A}$ and LeM ${ }_{3 d}{ }_{3 d} M^{C A}{ }_{7 d}$. The number of Pdx1expressing cells is markedly increased in LeM ${ }_{3 d}^{\mathrm{CA}}{ }_{3 \mathrm{MS}}{ }^{\mathrm{CA}}{ }_{7 \mathrm{~d}}$ compared with the LeMS ${ }^{\mathrm{CA}}$ condition. The majority of the Pdx1 ${ }^{+}$cells coexpress Neurog3. (f) Quantification of the proportion of transduced cells $\left(\mathrm{EGFP}^{+}\right)$expressing Neurog3 or Pdx1. The increase in the percentage of Neurog $3^{+}$is comparable in both protocols $\left(40 \pm 2 \%\right.$ in $\mathrm{LeM}^{\mathrm{CA}} \mathrm{Md}_{\mathrm{d}} \mathrm{MS}^{\mathrm{CA}}{ }_{7 \mathrm{~d}}$ versus $38 \pm 1 \%$ in LeMS $\left.{ }^{\mathrm{CA}} ; n=4 ; P>0.05\right)$; however, an increase can be detected in the percentage of PDX1 ${ }^{+}$cells with LeM ${ }_{3 \mathrm{da}} \mathrm{MS}^{\mathrm{CA}}{ }_{7 \mathrm{~d}}$ compared with LeMS $^{\mathrm{CA}}(28 \pm 3 \%$ in $\mathrm{LeM}^{\mathrm{CA}}{ }_{3 \mathrm{~d}} \mathrm{MS}^{\mathrm{CA}}{ }_{7 \mathrm{~d}}$ versus $8 \pm 1 \%$ in LeMS ${ }^{\mathrm{CA}} ; n=4 ;{ }^{*} P<0.05 ;{ }^{* \star} P<0.01$ ) 

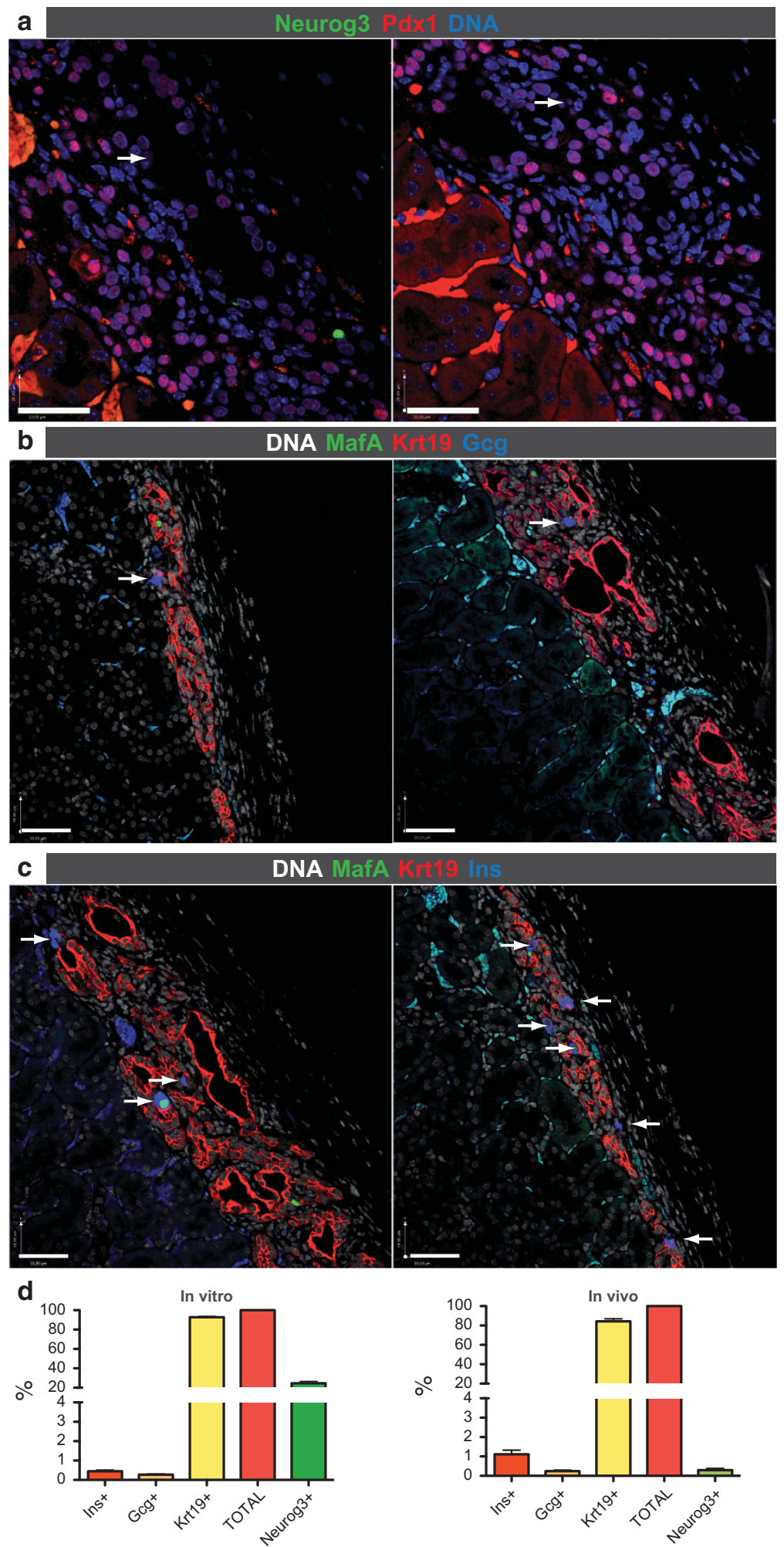

Figure 3 Engraftment of LeMCA3dMSCA7d monolayer-cultured human exocrine cells allows for in vivo maturation. (a-c) Immunohistochemical analysis of the graft-bearing kidney of immunodeficient mice transplanted with the human cells transduced with $\mathrm{LeM}^{\mathrm{CA}}{ }_{3 \mathrm{~d}} \mathrm{MS}^{\mathrm{CA}}{ }_{7 \mathrm{~d}}$. (a) In contrast to the in vitro cultures, a near total loss of Ngn3 expression is observed after transplantation of the LeM ${ }_{3 \mathrm{CA}} \mathrm{MS}^{\mathrm{CA}}{ }_{7 \mathrm{~d}}$ cells, whereas Pdx1 remains detectable in the majority of the epithelial cells. Bar: $35 \mu \mathrm{m}$. (b and c) All transplanted human cells remain $\mathrm{Krt19}^{+}$, except for the hormone ${ }^{+}$cells. (b) $\mathrm{Gcg}^{+}$cells were detected dispersed within the transplanted epithelial cells. (c) Following transplantation, insulin ${ }^{+}$cells appear within the graft. When analyzing the $\beta$-cell marker MafA, we observed only few insulin ${ }^{+}$cells coexpressing MafA, indicative of their immature nature. (d) Quantification of the protein expression after the transduction protocol $\mathrm{LeM}^{\mathrm{CA}}{ }_{3 \mathrm{~d}} \mathrm{MS}^{\mathrm{CA}}{ }_{7 \mathrm{~d}}$ before transplantation (in vitro) and after 42 days under the kidney capsule (in vivo). The most striking observation is the appearance of insulin ${ }^{+}$cells after in vivo transplantation combined with the disappearance of Neurog $3^{+}$cells. Gcg, glucagon 
cells; $n=4)$ cells were readily detected among LeMS ${ }_{F F / 3 D}$ but never among LeGFP ${ }_{\mathrm{FF} / 3 \mathrm{D}}$ cells (Figures $6 \mathrm{a}$ and $\mathrm{b}$ ). Acinar cells can thus be reprogrammed to insulin ${ }^{+}$cells when transduced with activated MAPK and STAT3 and cultured under free-floating/3D conditions. These observations demonstrate the plasticity of acinar cells and indicate that under appropriate conditions human acinar cells can be respecified to insulin ${ }^{+}$cells following transient expression of Neurog3. ${ }^{14}$

Long-term engraftment of LeMS ${ }^{\mathrm{CA}} \mathrm{FF}$ cells generates functional grafts capable of producing c-peptide and responding to increased glucose levels. Following engraftment of LeMS ${ }^{C A}$ FF cells under the kidney capsule of immunocompromised mice (Figure 1e), a significant rise in circulating human c-peptide could be observed from day 90 onwards (Figure 7a) $(n=4 ; P<0.05)$, whereas control mice never show a change in c-peptide levels. Injection of alloxan to destroy the endogenous rodent $\beta$ cells further increased the basal circulating $c$-peptide in $\mathrm{LeMS}^{\mathrm{CA}}{ }_{\mathrm{FF}}$ mice. Before alloxan injection, the blood glucose levels in LeMS ${ }^{\mathrm{CA}} \mathrm{FF}$ and LeGFP $_{F F}$ mice were similar. Following destruction of the endogenous $\beta$ cells, LeGFP ${ }_{F F}$ mice displayed a sharp increase in glycemia, whereas LeMS ${ }^{\mathrm{CA}}$ FF mice were able to attenuate and partially control the expected rise in blood glucose levels (on day $20616.6 \pm 0.5 \mathrm{mmol} / \mathrm{l}$ in $\mathrm{LeMS}^{\mathrm{CA}}{ }_{\mathrm{FF}}$ versus $32.7 \pm 0.3 \mathrm{mmol} / \mathrm{l}$ in LeGFP $\mathrm{FF} ; \quad P<0.01, \quad n=6$ ) (Figure $7 \mathrm{~b}$ ). Upon nephrectomy of the graft-bearing kidney, LeMS $^{\mathrm{CA}}$ FF mice became severely hyperglycemic and indistinguishable from controls (on day 212, $31.9 \pm 0.6 \mathrm{mmol} / \mathrm{l}$ in LeMS $^{\mathrm{CA}}{ }_{\mathrm{FF}}$ versus $33.0 \pm 0.2 \mathrm{mmol} / \mathrm{l}$ in LeGFP $\mathrm{FF} ; P>0.05$, $n=6)$. Intraperitoneal glucose tolerance test performed on day 208 demonstrated improved glucose tolerance of LeMS $^{\mathrm{CA}}$ FF mice compared with LeGFP ${ }_{\mathrm{FF}}$ mice. LeMS ${ }_{\mathrm{FF}}$ mice remained, however, more glucose intolerant compared to mice with mature human islet grafts (especially at 90 and 120 min postglucose injection) $(n=6 ; P<0.05)$ (Figure $7 \mathrm{c}$ ). Isolated grafts showed glucose responsiveness in vitro with a fivefold increase in secreted insulin levels when comparing low versus high glucose conditions $(n=3 ; P<0.05)$ (Supplementary Figure S6A). The $\beta$-like cells in the grafts, did not proliferate $\left(0.1 \pm 0.03 \% \mathrm{Ki} 7^{+}\right.$insulin $^{+}$cells in LeMS $^{\mathrm{CA}}$ FF grafts; $n=6$ ) (Supplementary Figure S6B). However, graft functionality was further demonstrated by serial transplantation with retrieved grafts able to attenuate blood glucose levels in secondary recipient mice (Supplementary Figure S6C).

Long-term engraftment of LeMS ${ }^{\mathrm{CA}}{ }_{\mathrm{FF}}$ cells generates insulin $^{+}$islet-like clusters. Engraftment of LeMS ${ }^{\mathrm{CA}}$ FF cells under the kidney capsule of immunocompromised mice during 210 days generates stable grafts readily detectable by GFP expression (Figure 7d). Upon closer examination, a substantial amount of insulin ${ }^{+}$cells was detected $(8.0 \pm 0.1 \%$; $n=6$ ) (Figure $7 e$ ). Whereas $29.6 \pm 1.2 \%$ of all cytokeratin $19+$ cells contained GFP, indicating the expression of activated MAPK and STAT3 $(n=6)$, insulin ${ }^{+}$cells seemed to have a higher prevalence of GFP $\left(65.5 \pm 9.0 \%\right.$ GFP $^{+}$insulin $^{+}$cells; $n=6$ ) (Figures $7 e$ and f). In addition, acinar-specific genetic lineage tracing (AdCela2A $A^{\mathrm{Cre}} /$ LeCMV-LSL-LacZ) (Figure 1f) revealed that although $27.1 \pm 1.2 \%$ of $\mathrm{Krt}^{+} 9^{+}$cells $(n=6)$ contained the acinar $\beta$-galactosidase ( $\beta$ gal) label, the fraction of insulin ${ }^{+}$cells expressing this genetic tracer was significantly higher $(61.7 \pm 8.8 \% ; n=6)$ (Figures $7 e$ and f). Insulin ${ }^{+}$ cells were organized in islet-like clusters and expressed high levels of Pdx1 (Figure 7f).

\section{Discussion}

Rodent acinar cells demonstrate a remarkable plasticity in culture that can be manipulated to transdifferentiate them to insulin $^{+}$cells for replacement therapy in diabetes. This reprogramming can be induced in cultured acinar cells from rat and mice by the combination of, respectively, EGF+LIF ${ }^{8}$ and $E G F+$ nicotinamide ${ }^{24}$ and in vivo in mouse pancreas by ectopic expression of three transcription factors, Neurog3, $P d x 1$ and $M a f A^{25}$ or by EGF+CNTF treatment of diabetic mice. ${ }^{26}$ In the present study, we focus on translating these original findings from rodent to man. We hypothesized that MAPK and STAT3 signaling, known effectors of EGF and LIF, may regulate the dedifferentiation of human acinar cells to a progenitor state and the subsequent redifferentiation to endocrine cells. ${ }^{10,14}$

Our data indicate that human acinar cells can undergo reprogramming upon introduction of activated MAPK+STAT3 $\left(\mathrm{MS}^{\mathrm{CA}}\right)$. In accordance with previous reports, ${ }^{13,22}$ acinar cells rapidly lost their identity during in vitro culture and the majority adopted a phenotype resembling pancreatic duct cells. However, in contrast to earlier studies, the key developmental transcription factor Neurog $3^{27-29}$ was re-expressed in MS ${ }^{\mathrm{CA}}$ cells. The expression of Neurog3 was transient when MS ${ }^{\mathrm{CA}}$ cells were transplanted. When human exocrine cells were transduced with $\mathrm{MS}^{\mathrm{CA}}$ and cultured as $2 \mathrm{D}$ monolayers, they initiated a proendocrine differentiation program. The endocrine differentiation was not completed, however, as the amount of insulin ${ }^{+}$and glucagon ${ }^{+}$cells did not increase. Compared with culture in free-floating aggregates, ${ }^{30}$ exocrine cells in 2D lost their Pdx1 expression, but by sequential transduction with LeMAPK and LeSTAT3, the number of $\mathrm{Pdx}^{+}$cells in $2 \mathrm{D}$ cultures increased again. By altering the culture conditions from 2D monolayer to 3D Matrigel, we observed enhanced endocrine differentiation of $\mathrm{MS}^{\mathrm{CA}}$ cells. Other studies have previously reported that alterations in cell polarity and cell-cell contact positively affect cell differentiation. ${ }^{19,20}$ By combining free-floating culture with 3D Matrigel culture, we further stimulated endocrine differentiation as illustrated by increased numbers of Neurog $3^{+}$and $\mathrm{Pdx}^{+}{ }^{+}$insulin ${ }^{+}$cells. The appearance of insulin ${ }^{+}$cells indicates that under these conditions of culture human exocrine cells transduced with $\mathrm{MS}^{\mathrm{CA}}$ are prone to terminal endocrine differentiation rather than acinoductal transdifferentiation. Possibly the free-floating preculture allows the acinar cells to adopt a state similar to embryonic pancreas progenitors, making these cells more susceptible to proendocrine signaling. ${ }^{30}$ In contrast to previous reports, ${ }^{31,32}$ the presence of activated MAPK did not activate the cell cycle as the fraction of proliferating cells was low in these cultures and did not differ from control cells.

When adult islet $\beta$ cells were subjected to $\mathrm{LeMS}^{\mathrm{CA}} \mathrm{FF/3D}$ treatment, Neurog3 expression was not activated. In addition, 
a
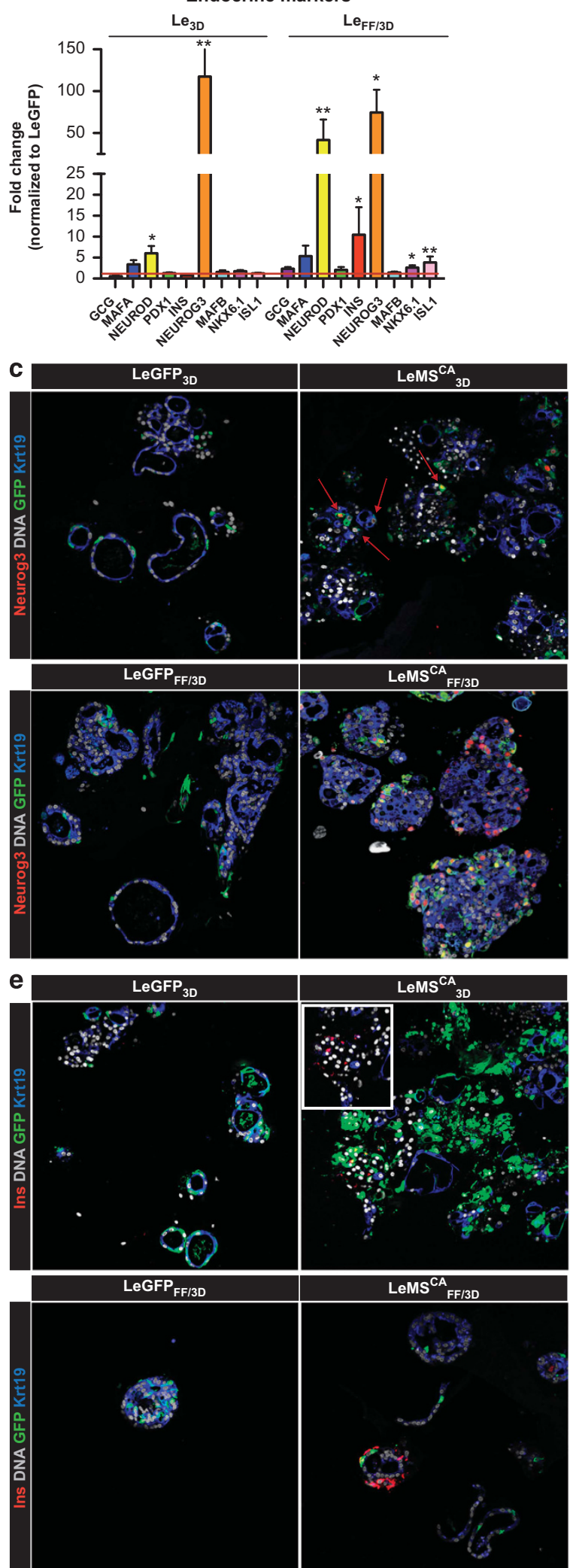

b

Exocrine markers
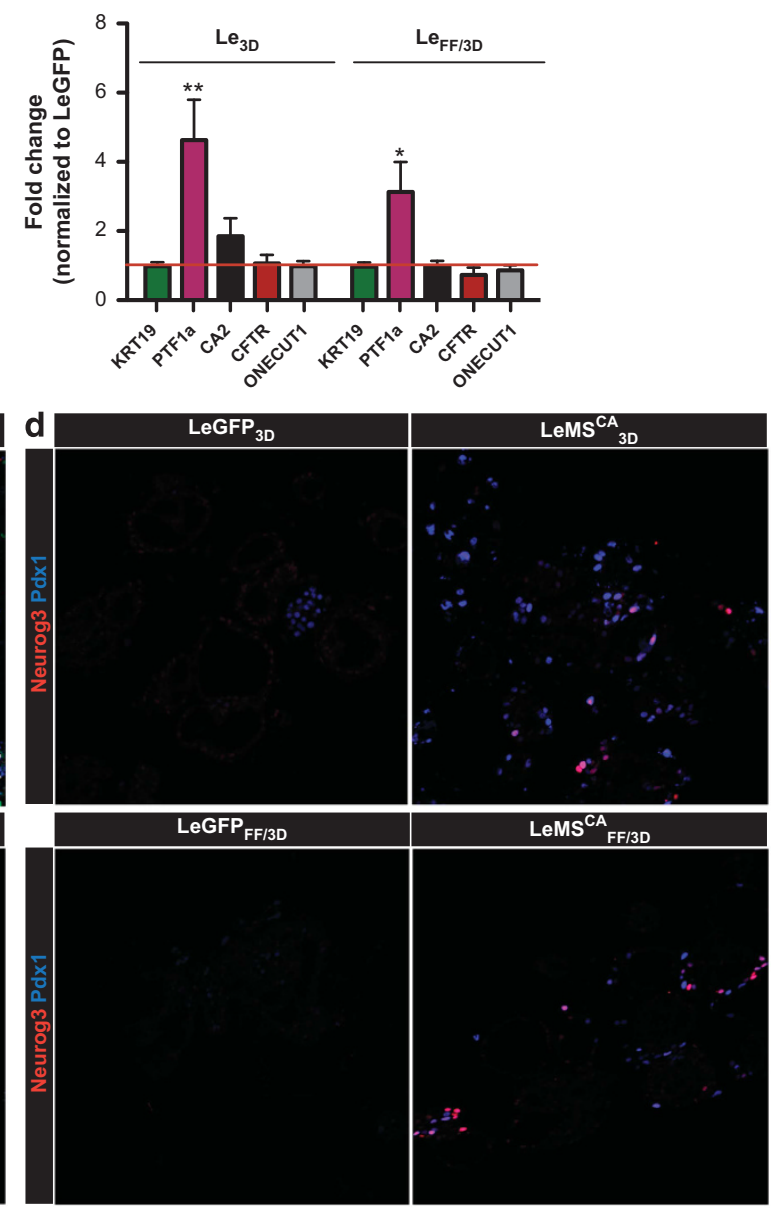

f
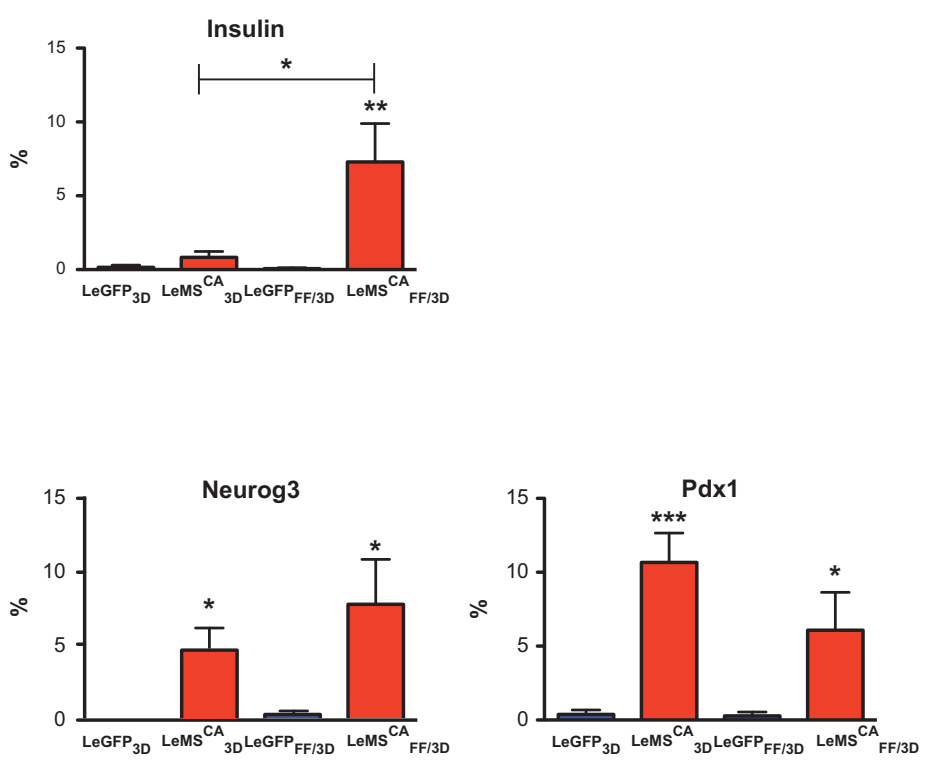
the expression of insulin, MafA and Pdx1 in adult islet $\beta$ cells was not influenced by LeMS ${ }^{\mathrm{CA}}$. These observations confirm the hypothesis that activated MAPK and STAT3 can convert human exocrine cells into $\beta$-like cells, and pre-existing $\beta$ cells are unlikely to be the source of the Neurog $3^{+}$or newly formed insulin ${ }^{+}$cells.

Engraftment of LeMS ${ }_{\mathrm{FF}}^{\mathrm{CA}}$ cells during an extended period of 210 days allowed the cells to acquire functionality. Under normoglycemic conditions, these mice displayed an increase in circulating human c-peptide starting around day 90 postengraftment. Upon chemical destruction of the endogenous rodent $\beta$ cell population, c-peptide levels further spiked and the sharp increase in blood glucose levels in controls was attenuated in LeMS ${ }^{\mathrm{CA}}{ }_{\mathrm{FF}}$ mice. In addition these animals showed an improved glucose tolerance, suggesting that these LeMS ${ }^{\mathrm{CA}}$ FF cells formed stable grafts able to respond to change in glycemia. Removal of the graft unequivocally identified the human cells as source of c-peptide and control over blood glucose levels. Moreover, serial transplantation revealed that these stable acinarderived grafts could partially correct blood glucose levels when transplanted into a new diabetic recipient mouse.

Genetic lineage tracing based on acinar cell-specific expression of a fluorescent reporter revealed that human acinar cells can not only give rise to duct-like cells (previously documented ${ }^{13}$ ) but also to cells expressing Neurog3 and insulin following the overexpression of MAPK and STAT3 in specific proendocrine culture conditions. A recent report demonstrated that human acinar cells in culture can give rise to insulin ${ }^{+}$cells following introduction of Neurog3, Pdx1 and MafA followed by a series of (epigenetic) signaling events, ${ }^{33}$ thus extrapolating the initial findings documented in mice in vivo. ${ }^{34}$ The present report, however, is the first to show that human acinar cells can initiate proendocrine differentiation by activated signaling without the introduction of transcription factors and thus opening the possibility of inducing endocrine differentiation with a combination of growth factors.

Duct cells have previously been shown to harbor the potential for endocrine differentiation. . $^{3,4,35}$ When ectopic Neurog3 is introduced in human duct cultures, these cells adopt an endocrine-like fate. ${ }^{35}$ Lack of lineage tracing in this mixed exocrine population does not allow the assessment of potential acinar contribution to this phenomenon. Others reported that adherent culture of human duct cells using overlay matrigel coating generates insulin ${ }^{+}$islets-like structures. ${ }^{3,4}$ These starting preparations did not include lineage tracing, and follow-up studies using $\beta$-cell-depleted exocrine preparations failed to reproduce these findings. ${ }^{5}$ Although the exocrine fractions used here initially contain a mixed population including mature duct cells, and human duct cells have previously been suggested to give rise to new $\beta$ cells, ${ }^{3,4}$ the absence of duct-specific lineage tracing does not allow us to speculate on the differentiation potential of human duct cells in the current study.

The number of $\mathrm{Neurog}^{+}$cells in $\mathrm{MS}^{\mathrm{CA}}$ cells was substantial but the absolute amount of insulin ${ }^{+}$cells remained low in vitro, even under the most optimal culture conditions tested. Shortterm engraftment of these cells only modestly improved endocrine differentiation. We did observe increased expression of MafA in some of the $\beta$-like cells after shortterm engraftment, suggesting improved in vivo maturation of the insulin ${ }^{+}$cells rather than ongoing differentiation of exo- to endocrine cells. In contrast, long-term engraftment of $\mathrm{MS}^{\mathrm{CA}}$ cells appeared to provoke a significant increase in human insulin $^{+}$cells, which are now organized in structures resembling islets. Interestingly, under these conditions, GFP expression seems to be enriched in $\beta$-like cells. This observation is suggestive of a preferential endocrine differentiation of $\mathrm{MS}^{\mathrm{CA}}$ cells following more than 200 days in vivo. Moreover, not only did we observe an increase in $\beta$-like cell numbers, genetic lineage tracing also showed that more than $60 \%$ of these insulin ${ }^{+}$cells originated from human acinar cells, compared with $30 \%$ of the duct-like population of the grafts.

The current report demonstrates for the first time that human acinar cells can adopt a $\beta$-like phenotype without the need to introduce a combination of pancreatic transcription factors. This acinoinsular reprogramming depends on 3D growth, activation of MAPK/STAT3 signaling and an intermediate Neurog $3^{+}$step. Given the volume of human acinar cells discarded upon clinical islet isolation, this approach may present an interesting strategy to increase the amount of transplantable $\beta$ cells provided the efficiency of cell-type conversion can be improved and the involvement of viruses avoided.

\section{Materials and Methods}

Human exocrine cells. Ethical approval to use exocrine-enriched cells derived from donor organs was given by the Medical Ethical Committee of the University Hospital of the Vrije Universiteit Brussel (Brussels, Belgium; OG 016) to the Beta Cell Bank-University Hospital Brussels (permission 2010/193). The human exocrine fraction was obtained from heart-beating cadaveric non-diabetic donors as

Figure 4 Overexpression of MAPK ${ }^{\mathrm{CA}}$ and STAT3 ${ }^{\mathrm{CA}}$ promotes re-expression of Ngn3 and Pdx1 and endocrine differentiation in 3D matrix cultures in vitro. (a and $\left.\mathbf{b}\right)$ Gene expression profile of endocrine (a) and exocrine markers (b). LeMS conditions are normalized to control conditions (LeGFP) set at 1 (red line). In LeMSCA3D condition, we observed a significant increase in NEUROD and NEUROG3 transcripts compared with controls. These observations were mirrored in the LeMS ${ }_{\mathrm{FF}}{ }^{3 \mathrm{DD}} \mathrm{COndition}$ with additional increase in INS, NKX6.1 and ISL1 transcripts. Both the ${ }_{\text {LeMSCA3D }}$ and LeMS ${ }^{C A}$ FF/3D condition showed a modest but significant increase in $P$ PF $1 A$ transcripts $(n=5)\left({ }^{*} P<0.05\right.$; $\left.{ }^{* *} P<0.01\right)$. (c-e) Immunocytochemical analysis after 3D culture (LeMSCA3D) and the free-floating culture followed by 3D culture (LeMS $\left.{ }^{\mathrm{CA}}{ }_{\mathrm{FF} / 3 \mathrm{D}}\right)$. (c) Both in the $\mathrm{LeMSCA3D}$ and LeMS $^{\mathrm{CA}}{ }_{\mathrm{FF} / 3 \mathrm{D}}$ condition, Neurog $3^{+}$cells can be detected in transduced $\left(\mathrm{EGFP}^{+}\right)$cells. The majority of these $\mathrm{Ngn}^{+}$cells coexpress the ductal marker Krt19. Cells expressing Neurog3 protein were never observed in the corresponding control conditions (LeGFP ${ }_{3 D}$ and LeGFP $\mathrm{FF}_{3 \mathrm{D}}$ ). (d) In the $\mathrm{LeMSCA3D}_{\mathrm{D}}$ and LeMS ${ }_{\mathrm{FF} / 3 \mathrm{D}} \mathrm{Condition}^{\mathrm{CA}}$, cells expressing high levels of Pdx1 protein can be detected. A fraction of these cells displayed coexpression with Neurog3. Cells expressing high Pdx1 protein were only rarely observed in the corresponding control conditions (LeGFP ${ }_{3 \mathrm{D}}$ and LeGFP $\mathrm{FF} / 3 \mathrm{D}$ ). (e) $\mathrm{LeMS}_{3 \mathrm{D}}^{\mathrm{CA}}$ and $\mathrm{LeMS}^{\mathrm{CA}}{ }_{\mathrm{FF} / 3 \mathrm{D}}$ conditions show for the first time the presence of INS ${ }^{+}$cells in vitro. These insulin ${ }^{+}$ cells do not express the ductal marker Krt19. (f) Quantification of the proportion of cells expressing the different phenotypical markers. A significant increase in the number of insulin $^{+}$cells can be observed in the LeMS ${ }_{\mathrm{FF} / 3 \mathrm{D}}$ condition $\left(7.3 \pm 2.6 \%\right.$ in LeMS ${ }_{\mathrm{FF} / 3 \mathrm{D}}(n=7)$ versus $0.83 \pm 0.40 \%$ in LemSCA3D $(n=8)$ and $0.06 \pm 0.06 \%$ in LeGFP ${ }_{\mathrm{FF} / 3 \mathrm{D}}$ $\left.(n=10) ;{ }^{*} P<0.05 ;{ }^{*} P<0.01\right)$. The percentage of Neurog $3^{+}$and $P d x 1^{+}$cells is significantly increased in both ${ }_{\text {LeMSCABD }}$ and LeMS ${ }^{\mathrm{CA}}{ }_{\mathrm{FF} / 3 \mathrm{D}}$ Conditions compared with controls $\left({ }^{\star} P<0.05 ;{ }^{* \star *} P<0.001\right)$ 
a
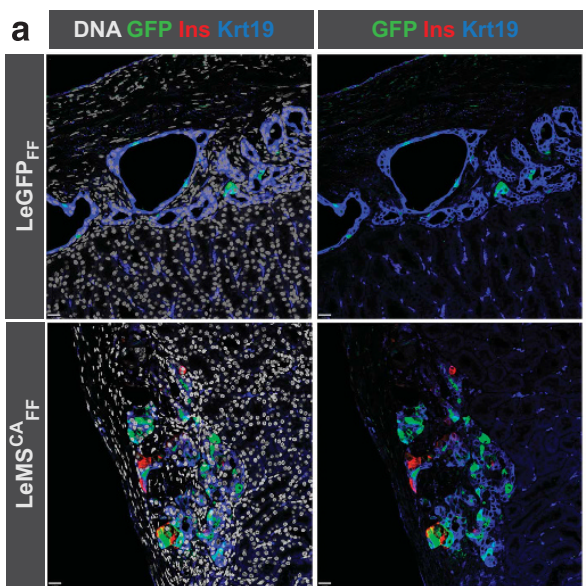

b DNANG

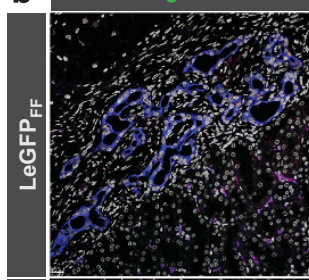

Neurog 3
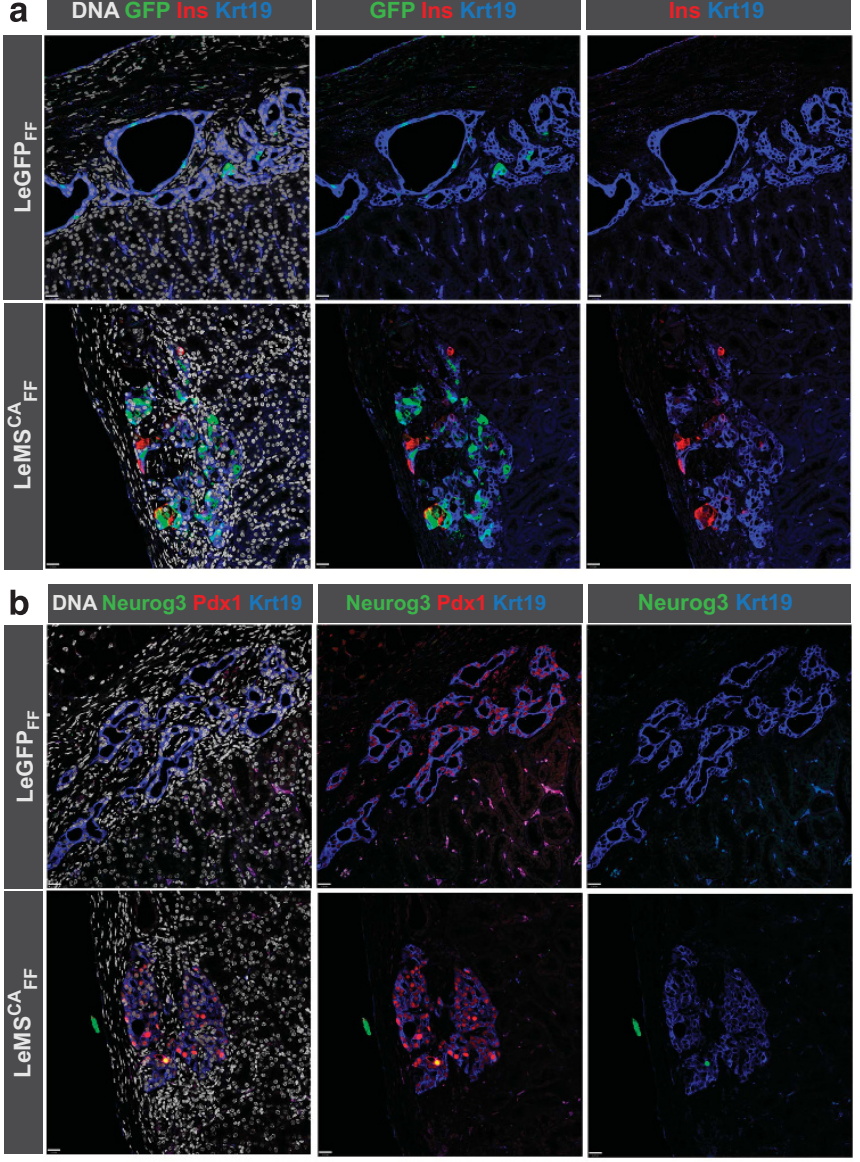

c

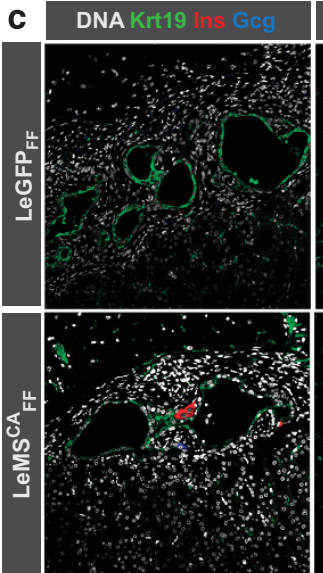

Krt19
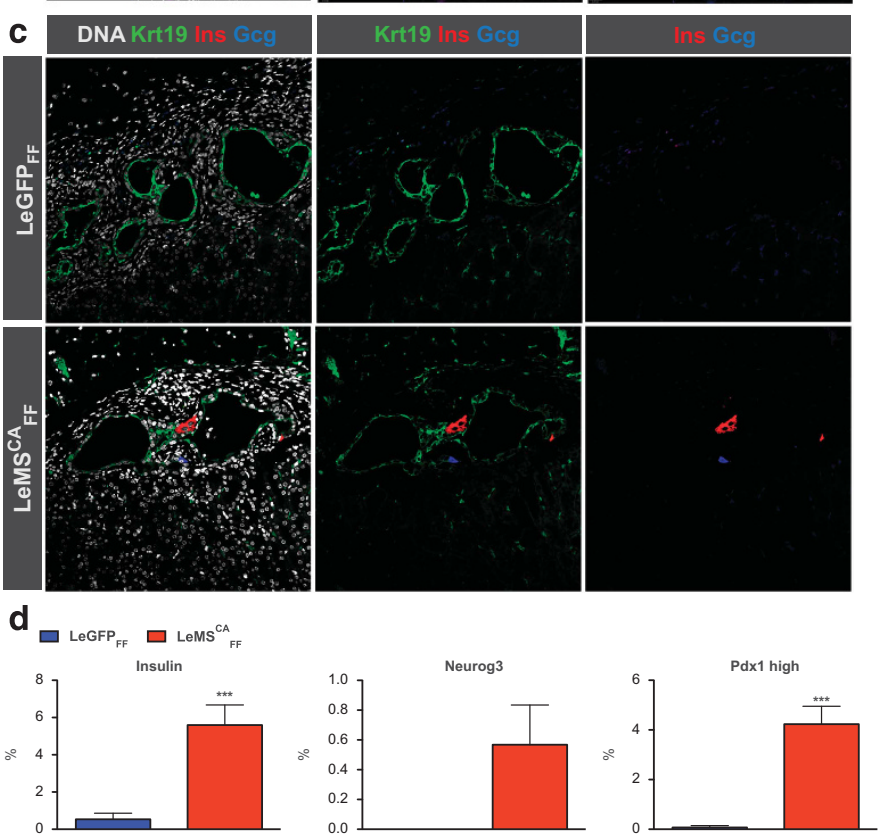

Figure 5 Short-term transplantation of LeMSCAFF cells yields a limited number of insulin+ cells. (a and c) Immunohistochemical analysis of LeMS ${ }^{C A}{ }_{F F}$ human exocrine cells following 42-day engraftment under the kidney capsule of immunodeficient mice. (a) In contrast to the cell preparation before transplantation, insulin ${ }^{+}$cells can be observed in LeMS $^{\mathrm{CA}}{ }_{\mathrm{FF}}$ condition after engraftment in vivo. LeGFP $\mathrm{FF}$ controls never showed an increase in the fraction of insulin ${ }^{+}$cells (b) Pdx1 expression is prominent in the majority of the $\mathrm{Krt}_{1} 9^{+}$epithelial cells both in LeGFP $\mathrm{FF}$ and LeMS ${ }_{\mathrm{FF}}$ conditions (the latter contains more cells with high Pdx1 expression). However, compared with the cell preparation before

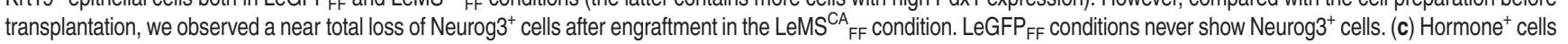
$\left(\mathrm{INS}^{+}\right.$or $\mathrm{Gcg}^{+}$) do not express the ductal marker Krt19. (d) Quantification of the fraction of cells expressing insulin, Neurog3 or high levels of Pdx1 protein in LeGFP $\mathrm{FF}$ and

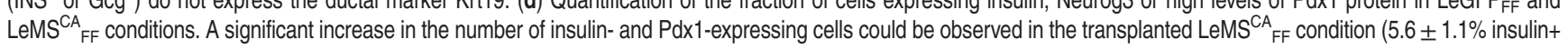
cells $(n=10) ; 4.2 \pm 0.7 \%$ Pdx $1+$ cells $\left.(n=5) ;{ }^{* * *} P<0.001\right)$. Gcg, glucagon 

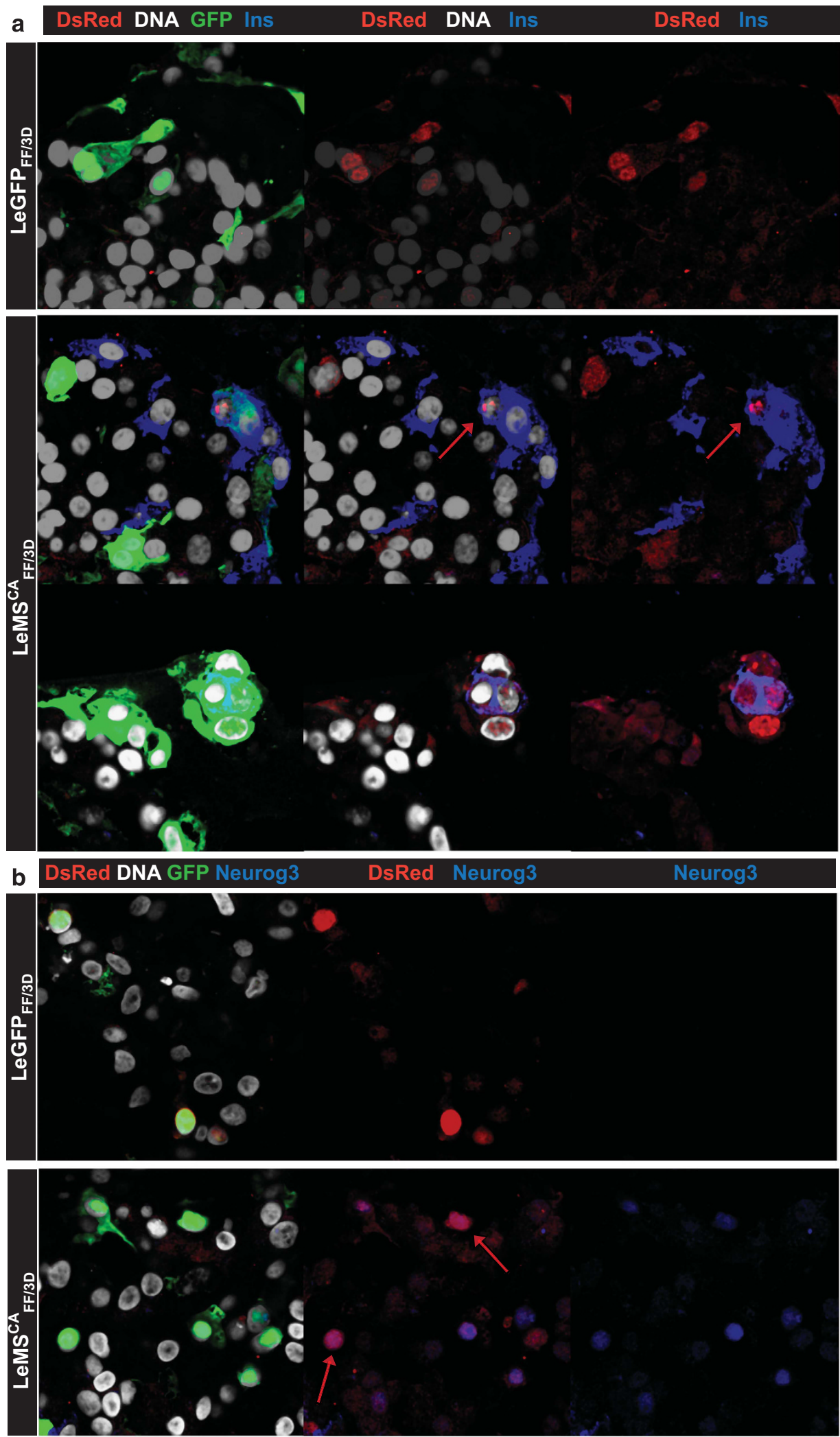

Figure 6 Genetic lineage tracing of human acinar cells reveals acinar to $\beta$-cell transdifferentiation To trace the fate of adult human acinar cells in our culture system, the cells were transduced with Cre recombinase under the control of the acinar-specific elastase $2 \mathrm{~A}$ promoter and the reporter construct CMV-LSL-nls-DsRed. (a) Original acinar cells identified by the presence of the DsRed fluorescent protein were readily detected in both LeGFP $\mathrm{FF}_{3 / 3 \mathrm{D}}$ and LeMS ${ }_{\mathrm{FF} / 3 \mathrm{D}}$ conditions. However, insulin ${ }^{+} / \mathrm{DsRed}^{+}$cells were only detected in LeMS ${ }^{\mathrm{CA}}{ }_{\mathrm{FF} / 3 \mathrm{D}}$ condition but never in the LeGFP $\mathrm{FF}_{3 \mathrm{D}}$ control. Every insulin $/ \mathrm{DSR} \mathrm{R}^{+}$cell in the latter condition also contained the GFP label, indicative of transduction with MAPK ${ }^{\mathrm{CA}}-\mathrm{STAT}^{\mathrm{CA}}$. (b) Neurog $3^{+}$cells containing the acinar lineage tracer DsRed were observed in the $\mathrm{LeMS}^{\mathrm{CA}} \mathrm{FF} / 3 \mathrm{D}$ condition only, as Neurog3 ${ }^{+}$cells were never detected in the control condition 
a
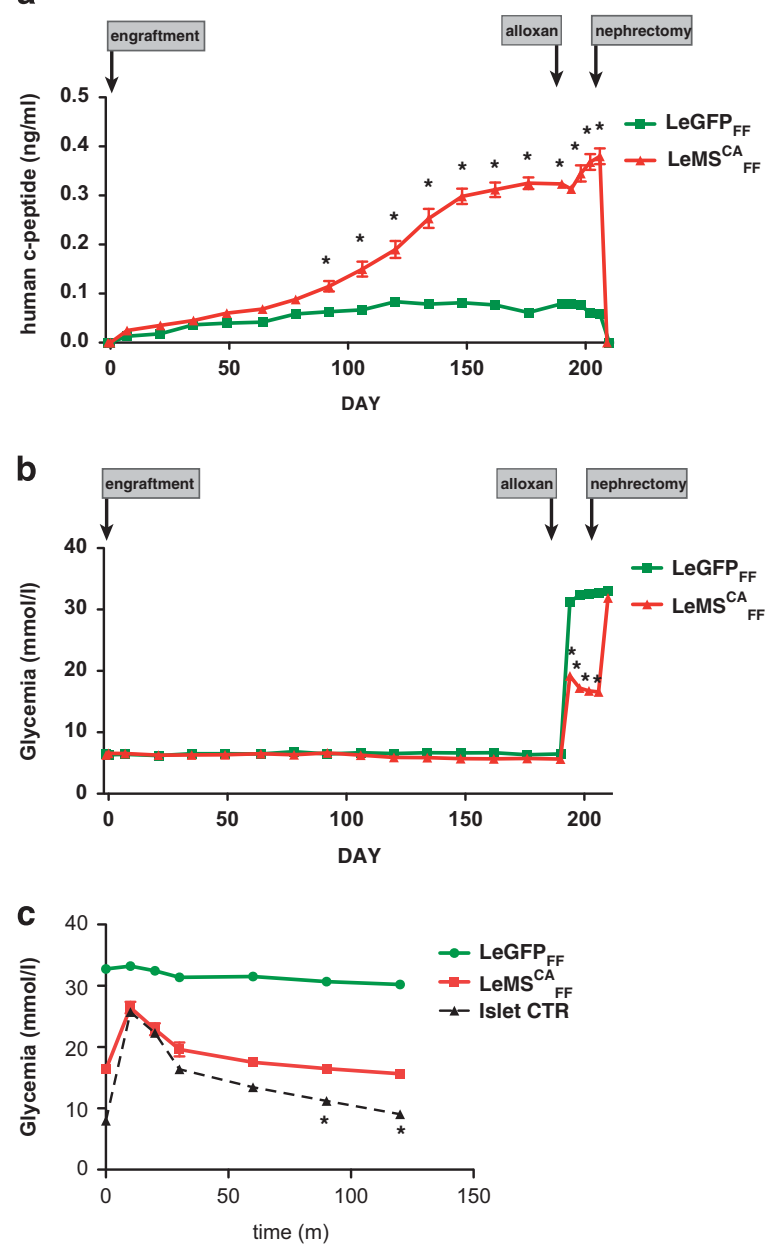

d

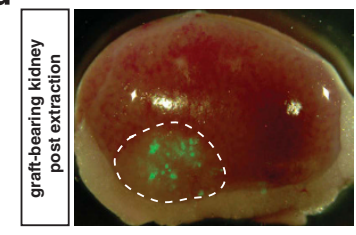

e

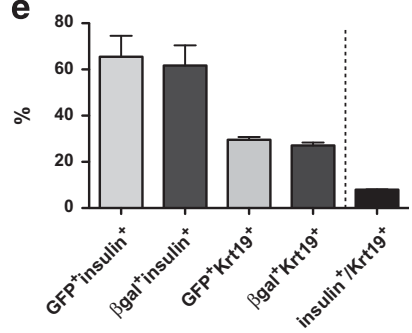

f

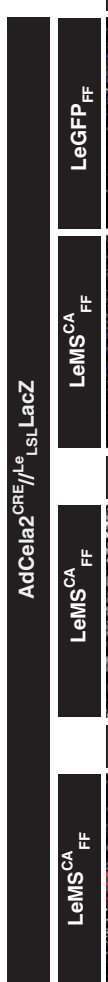

DNA
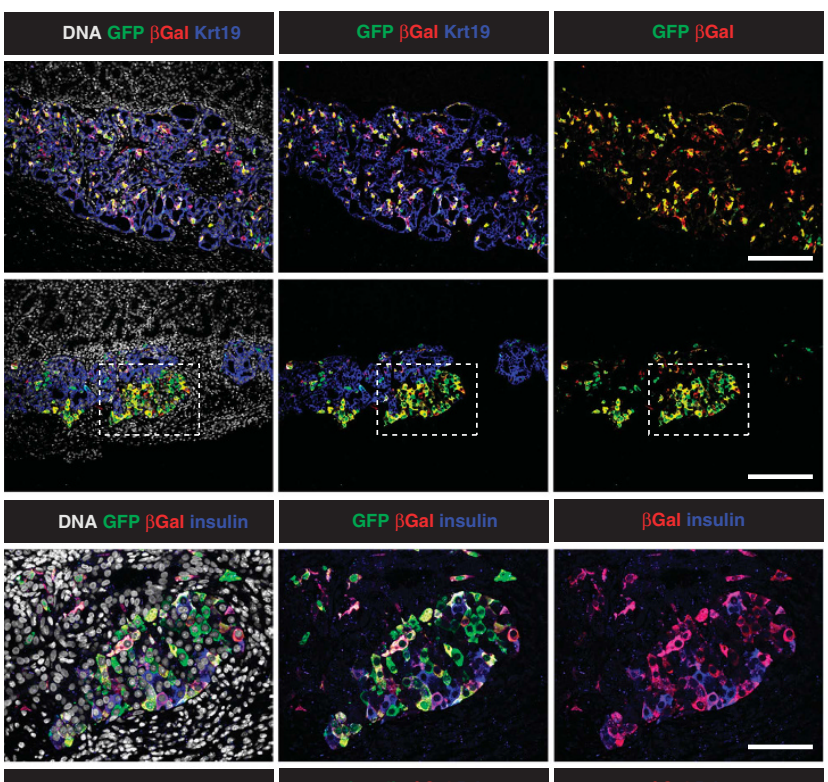

DNA
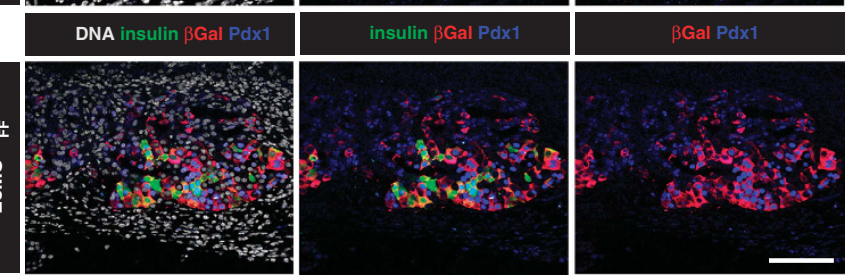

Figure 7 Long-term engraftment generates acinar-derived islet-like clusters in vivo. (a) Circulating human c-peptide levels in mice engrafted with either LeGFP $\mathrm{FF}$ or $\mathrm{LeMS}^{\mathrm{CA}}{ }_{\mathrm{FF}}$ cells. Significantly increased levels of c-peptide are detected in LeMS ${ }_{\mathrm{FF}}$ mice from day 90 postengraftment. C-peptide levels become stable around day 148 $\left(0.30 \pm 0.02 \mathrm{ng} / \mathrm{ml}\right.$ in LeMS ${ }_{\mathrm{FF}}$ versus $0.08 \pm 0.02 \mathrm{ng} / \mathrm{ml}$ in LeGFP FF; $\left.P<0.01, n=6\right)$. After alloxan injection, c-peptide levels in LeMS ${ }^{\mathrm{CA}}{ }_{\mathrm{FF}} \mathrm{mice}$ further increased to $0.38 \pm 0.02 \mathrm{ng} / \mathrm{ml}$. No human c-peptide could be detected after nephrectomy of the graft-bearing kidney at day 210. (b) Blood glucose levels in mice engrafted with either LeGFP $_{\mathrm{FF}}$ or LeMS CA ${ }_{\mathrm{FF}}$ cells. Before alloxan injection, both groups are indistinguishable (on day 190,6.3 $\pm 0.2 \mathrm{mmol} / \mathrm{lin} \mathrm{LeMS}^{\mathrm{CA}}{ }_{\mathrm{FF}}$ versus $5.8 \pm 0.2 \mathrm{mmol} / \mathrm{lin} \mathrm{LeGFP} \mathrm{FF}_{\mathrm{FF}} ; P>0.05$, $n=6$ ). After alloxan injection, blood glucose levels of LeMS CA ${ }_{\mathrm{FF}}$ mice remain significantly lower compared with LeGFP mice (on day $206,16.6 \pm 0.5 \mathrm{mmol} / \mathrm{lin}$ LeMS ${ }^{\mathrm{CA}} \mathrm{FF}_{\mathrm{F}}$ versuS $32.7 \pm 0.3 \mathrm{mmol} / \mathrm{l}$ in LeGFP $\mathrm{FF} ; P<0.01, n=6$ ). Removal of the graft-bearing kidney provoked an acute reversal to hyperglycemia in LeMS ${ }_{\mathrm{FF}}^{\mathrm{CA}}$ mice (on day 212 , $31.9 \pm 0.6 \mathrm{mmol} / \mathrm{l}$ versus $33.0 \pm 0.2 \mathrm{mmo} / /$ in LeGFP $\mathrm{FF} ; P<0.01, n=6$ ). (c) Intraperitoneal glucose tolerance test (IPGTT). Two micrograms of glucose per $\mathrm{kg}$ body weight was injected and clearance in blood was measured at indicated time points to indirectly measure the glucose responsiveness of insulin secretion by $\beta$ cells ( ${ }^{*} P<0.05 ; n=6$ each). (d) Two hundred and ten days after engraftment of LeMS ${ }^{\mathrm{CA}}{ }_{\mathrm{FF}}$ cells results in stable grafts visualized by GFP expression. (e) Immunohistochemical analyses showed an increased fraction of insulin ${ }^{+}$cells in LeMS ${ }^{\mathrm{CA}}$ FF conditions to almost $10 \%$. Whereas GFP was detected in only $30 \%$ of the Krt $19^{+}$cells at the time of analysis, GFP was found in over $60 \%$ of the insulin ${ }^{+}$cells, indicating a preferential differentiation of LeMS ${ }^{\mathrm{CA}}{ }_{\mathrm{FF}}$-transduced cells to a $\beta$-like phenotype. Genetic lineage tracing using the acinar-specific elastase $2 \mathrm{~A}$ promoter and the reporter construct CMV-LSL-LacZ revealed that $61 \%$ of the insulin ${ }^{+}$cells originated from acinar cells, whereas the same holds true for $30 \%$ of the Krt $19^{+}$cells.

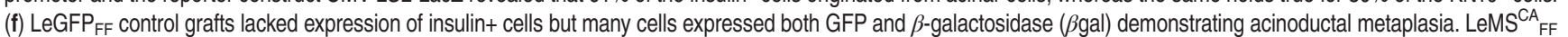
grafts, however, contained clusters of cells devoid of Krt19 expression while clearly positive for GFP and the acinar-specific $\beta$ gal label. Closer examination demonstrated the expression of insulin and Pdx1 in these LeMS ${ }^{C A}$ FF $\beta$-like cells (scale bars $=100 \mu \mathrm{m}, 25 \mu \mathrm{m}$ and $30 \mu \mathrm{m}$ )

the discarded fraction from islet cell isolation for the purpose of clinical transplantation in type 1 diabetes patients. Human donors aged between 18 and 67 years (median age $=51$ years) and had a male-to-female ratio of $1.3(n=16)$. In the exocrine fraction, starting preparations contain $~ 60 \%$ acinar, $35 \%$ duct, $1-3 \%$ endocrine and $1-2 \%$ mesenchymal cells. After a culture period of at least 4 days, these preparations contain $1.5 \%$ of cells expressing endocrine cell markers and $90 \%$ expressing the duct cell-specific phenotypic markers Krt19 and carbohydrate antigen 19.9. ${ }^{36}$
Animals. All animal experimentations were performed in agreement with the regulations approved by the ethical committee of the Free University of Brussels. Eight-week-old NOD.CB17-Prkdc scid/NCrCrl or C.B-17/lcrHsd-PrkdcscidLystbg-J mice and BALB/CAnNCrl-nuBR nude mice (Charles River Laboratories, L'Arberesle, France) weighing 22-28 $\mathrm{g}$ were used as recipients for transplantation.

Lineage tracing. Acinar lineage tracing was achieved by the combination of an adenovirus expressing Cre recombinase under the control of a $550 \mathrm{~kb}$ human 
Table 1 List of primer sequences

\begin{tabular}{|c|c|c|}
\hline Gene & Primer reference & Source \\
\hline NEUROG3 & Hs56a19734677 & IDT \\
\hline PAX4 & Hs00173014_m1 & Applied Biosystems \\
\hline INS & Hs56a21254175 & IDT \\
\hline$N K X 6.1$ & Hs00232355_m1 & Applied Biosystems \\
\hline$N K X 2.2$ & Hs00159616_m1 & Applied Biosystems \\
\hline$P D X 1 / I P F 1$ & Hs00236830_m1 & Applied Biosystems \\
\hline HLXB9 & Hs00232128_m1 & Applied Biosystems \\
\hline$G C G$ & Hs00174967_m1 & Applied Biosystems \\
\hline$M A F A$ & Hs01651425_s1 & Applied Biosystems \\
\hline NEUROD & $\mathrm{Hs} 00159598 \mathrm{~m} 1$ & Applied Biosystems \\
\hline ISL1 & Hs00158126_m1 & Applied Biosystems \\
\hline PTF1a & $\mathrm{Hs} 00603586 \mathrm{~g} 1$ & Applied Biosystems \\
\hline MIST1 & Hs56a21101745 & IDT \\
\hline AMYLASE & Hs56a38779302 & IDT \\
\hline ELASTASE & Hs56a24621883 & IDT \\
\hline TCF2 & Hs56a25568705 & IDT \\
\hline $50 \times 9$ & Hs56a38984663 & IDT \\
\hline CK19 & Hs01051611_gH & Applied Biosystems \\
\hline ONECUT1 & $\mathrm{Hs} 00413554 \mathrm{~m} 1$ & Applied Biosystems \\
\hline CA2 & Hs00163869_m1 & Applied Biosystems \\
\hline CFTR & Hs00357011_m1 & Applied Biosystems \\
\hline PPIA & Hs39a22214851 & IDT \\
\hline
\end{tabular}

pancreatic elastase $2 \mathrm{~A}$ promoter fragment (Ad-Cela- $2 A^{\mathrm{Cre}}$ ) and a lentivirus expressing either DsRed or LacZ preceded by a stop sequence flanked by loxP sites, under the control of the constitutive active CMV promoter (Le-CMV-LSLDsRed/LacZ). This allows for indefinite labeling of acinar cells.

Experimental model. $\beta$-Cell neogenesis was induced in exocrine cell cultures after a differentiation period of 7 days monolayer culture, 7 days $3 \mathrm{D}$ matrix culture or a sequential period of 10 days suspension followed by 7 days $3 \mathrm{D}$ matrix. The matrix constitutes undiluted Matrigel Matrix Growth Factor Reduced (Matrigel GFR; BD Biosciences, San Jose, CA, USA). Human exocrine cells were transduced directly after isolation with lentiviruses expressing activated MAPK and STAT3. The cells were cultured in RPMI-1640 medium supplemented with 1\% FBS (Life Technologies, Grand Island, NY, USA).

Reverse transcription-PCR. Total RNA was isolated using the RNeasy Mini Kit (Qiagen, Valencia, CA, USA; 74106) and was transcribed and amplified as described by the manufacturer using blanks in each assay.

Quantitative PCR was performed using TagMan Fast Universal PCR Master Mix (Applied Biosystems, Grand Island, NY, USA; 4364103) with selected primers (Table 1). Two replicate reactions were used for every sample. In addition, a positive control was used and all expression levels were normalized to the housekeeping gene PPIA (peptidylpropyl isomerase A or cyclophilin-A). ${ }^{37}$ Nuclease-free water was run as a negative control.

Viral constructs. Constitutively active STAT3 was generated by site-directed mutagenesis using the primer $5^{\prime}$-GCTATAAGATCATGGATTGTACCTGCATCCT GGTGTCTCC-3' (a kind gift from JE Darnell). ${ }^{38}$ The STAT3 ${ }^{\text {CA }}$ was ligated in a Spel/Xmal-digested pTrip-CMV-eGFP-Nhelpoly-invPGK vector generating pTripCMV-eGFP-Nhelpoly-invPGK-STAT $3^{\text {CA }}$. From the pTrip plasmid, a lentivirus production was started following the described protocol.

Constitutively active MAPK1 was generated by constructing a fusion between native ERK2 and MEK1, and subsequential mutation of four leucine residues in the export signal region to alanine, generating a hyperactivated MAPK1. The pG5E4D38CMV5-MAPK ${ }^{\mathrm{CA}}$ vector is a kind gift from Cobb and co-workers. ${ }^{39} \mathrm{CMV}^{\mathrm{CMAPK}}{ }^{\mathrm{CA}}$ was transferred to a pTrip vector by Sal/Nhel ligation, generating a pTrip-CMV-MAPK ${ }^{C A}$. ires-eGFP vector, which was used for lentivirus production.

Combining both single vectors to a single pTrip-CMV-MAPK ${ }^{\text {CA }}$-ires-eGFPNhelpoly-invPGK- STAT $3^{\mathrm{CA}}$ vector generated a bicistronic vector expressing both MAPK $^{\text {CA }}$ and STAT3 ${ }^{\text {CA }}$.

Immunostaining. Immunocytochemistry was performed in 24-well plates. IHC was performed on paraffin sections. ${ }^{36}$ The different antibodies used can be found in Table 2.
Table 2 List of primary antibodies

\begin{tabular}{lll}
\hline Antibody & Description & Source \\
\hline GFP & Goat anti-GFP-biotin & Abcam (Cambridge, MA, USA) \\
Neurog3 & Rabbit anti-Ngn3 & M German \\
Ins & Guinea-pig anti-insulin & C Van Schravendijk \\
CK19 & Mouse anti-CK19 & Dako (Glostrup, Germany) \\
MafA & Rabbit anti-MafA & A Rezania \\
Gcg & Mouse anti-glucagon & Sigma \\
Pdx1 & Guinea-pig anti-Pdx1 & C Wright \\
DsRed & Rabbit anti-RFP & Abcam \\
Chymo & Rabbit anti-Chymo & Millipore \\
Sox9 & Rabbit anti-Sox9 & Chemicon (Billerica, MA, USA)
\end{tabular}

Microscopy. All images were acquired with a Zeiss LSM710 NLO TiSa multiphoton confocal microscope using Zeiss Zen2011 software (Carl Zeiss NV-SA, Zaventem, Belgium). All pictures were analyzed with VolocityLE software (Improvision, Coventry, UK).

Transplantation. Cells were detached using $0.25 \%$ Collagenase-V (Sigma (St. Louis, MO, USA); 9001-12-1) for the monolayers. After exposing the left kidney, a small incision was made in the kidney capsule. The cells were collected in a catheter and delivered under the kidney capsule using a microdispenser pipet (Mitutoyo, Aurora, IL, USA). An average of 300000 human exocrine cells was engrafted under the kidney capsule. Per human donor, three mice were engrafted and six independent donors were used for transplantation.

Metabolic studies. Blood glucose levels were monitored in tail vein samples (Glucocard Memory Strips; A Menarini Diagnostics Benelux, Zaventem, Belgium). Mice were fasted during $6 \mathrm{~h}$ and injected intraperitoneally with glucose $(2 \mathrm{~g}$ per $\mathrm{kg}$ body weight) for glucose tolerance tests, and blood glucose concentration was measured from tail vein blood with a portable glucometer. Plasma c-peptide concentration was determined with the Human C-peptide ELISA Kit (Millipore, Billerica, MA, USA). For GSIS analysis, pancreatic islets were isolated by collagenase digestion, handpicked and pooled. Secreted insulin levels were determined at low ( $2 \mathrm{~h}$ at $2.5 \mathrm{mM}$ glucose) and high ( $2 \mathrm{~h}$ at $20 \mathrm{mM}$ glucose) concentrations. The level was determined with the Human Insulin ELISA Kit (Millipore).

Statistical analysis. GraphPad Prism version 5.0b was used to create the graphs and perform the statistics (GraphPad Prism, La Jolla, CA, USA). Results compared with their control set at 1 were analyzed using a one-sample Student's $t$-test. When two treatment groups were compared, a two-tailed Student's $t$-test was used. Mean values are presented as the mean \pm S.E.M. The number of independent experiments is indicated in the text. $\mathrm{N}$-values represent independent human donors.

\section{Conflict of Interest}

The authors declare no conflict of interest.

Acknowledgements. Special thanks to Katherine Yang, Vinh Nguyen, Gregory Szot, Veerle Laurysens, Ann Demarré, Erik Quartier and Jan De Jonge for technical advice and assistance, Daniel Pipeleers for logistic support and Matthias Hebrok for helpful discussions. LBa is a postdoctoral fellow of the Research Foundation - Flanders (FWO). This work was financially supported by the Research Foundation - Flanders (FWO) (HH, LBa and LBo), the JDRF ( $\mathrm{HH}$, LBo and LBa), the European Foundation for the Study of Diabetes (EFSD) (LBo and LBa), the European Union Sixth (No. LSHB-CT-2005-512145), Seventh (HEALTH-F5-2009-241883) Framework Program (HH and LBo), NIH P3O DK063720 and Leona M and Harry B Helmsley Charitable Trust (2012PG-T1D017) (MSG) and the laccoca Family Foundation (MSG, LBa).

\section{Author contributions}

Design: $\mathrm{ML}$ and $\mathrm{LBa}$; execution of experiments: $\mathrm{ML}, \mathrm{LBa}, \mathrm{GL}$ and $\mathrm{YH}$; analyses: $\mathrm{ML}$ and LBa; interpretation of results: ML, MSG, HH and LBa; writing: ML, MSG, HH and LBa; project management: $\mathrm{HH}, \mathrm{LB}$ and LBa. 
23. Klein T, Heremans Y, Heimberg H, Pipeleers D, Madsen OD, Serup P et al. Investigation and characterization of the duct cell-enriching process during serum-free suspension and monolayer culture using the human exocrine pancreas fraction. Pancreas 2009; 38: 36-48.

1. Bouwens L, Lu WG, De Krijger R. Proliferation and differentiation in the human fetal endocrine pancreas. Diabetologia 1997; 40: 398-404

2. Meier JJ, Butler AE, Saisho Y, Monchamp T, Galasso R, Bhushan A et al. Beta-cell replication is the primary mechanism subserving the postnatal expansion of beta-cell mass in humans. Diabetes 2008; 57: 1584-1594.

3. Bonner-Weir S, Taneja M, Weir GC, Tatarkiewicz K, Song KH, Sharma A et al. In vitro cultivation of human islets from expanded ductal tissue. Proc Natl Acad Sci USA 2000; 97: 7999-8004.

4. Gao R, Ustinov J, Pulkkinen MA, Lundin K, Korsgren O, Otonkoski T et al. Characterization of endocrine progenitor cells and critical factors for their differentiation in human adult pancreatic cell culture. Diabetes 2003; 52: 2007-2015.

5. Gao R, Ustinov J, Korsgren O, Otonkoski T. In vitro neogenesis of human islets reflects the plasticity of differentiated human pancreatic cells. Diabetologia 2005; 48: 2296-2304.

6. Rooman I, Heremans Y, Heimberg H, Bouwens L. Modulation of rat pancreatic acinoductal transdifferentiation and expression of PDX-1 in vitro. Diabetologia 2000; 43: 907-914.

7. Bouwens L. Cytokeratins and cell differentiation in the pancreas. J Pathol 1998; 184 234-239.

8. Baeyens L, De Breuck S, Lardon J, Mfopou JK, Rooman I, Bouwens L et al. In vitro generation of insulin-producing beta cells from adult exocrine pancreatic cells. Diabetologia 2005; 48: 49-57

9. Lardon J, De Breuck S, Rooman I, Van Lommel L, Kruhøffer M, Orntoft T et al. Plasticity in the adult rat pancreas: transdifferentiation of exocrine to hepatocyte-like cells in primary culture. Hepatology 2004; 39: 1499-1507.

10. Baeyens L, Bonné S, Bos T, Rooman I, Peleman C, Lahoutte T et al. Notch signaling as gatekeeper of rat acinar-to-beta-cell conversion in vitro. Gastroenterology 2009; 136 1750-1760 e1713.

11. Minami K, Okuno M, Miyawaki K, Okumachi A, Ishizaki K, Oyama K et al. Lineage tracing and characterization of insulin-secreting cells generated from adult pancreatic acinar cells. Proc Natl Acad Sci USA 2005; 102: 15116-15121.

12. Okuno M, Minami K, Okumachi A, Miyawaki K, Yokoi N, Toyokuni S et al. Generation of insulin-secreting cells from pancreatic acinar cells of animal models of type 1 diabetes. Am J Physiol Endocrinol Metab 2007; 292: E158-E165.

13. Houbracken I, de Waele E, Lardon J, Ling Z, Heimberg H, Rooman I et al. Lineage tracing evidence for transdifferentiation of acinar to duct cells and plasticity of human pancreas. Gastroenterology 2011; 141: 731-741 and 731-734.

14. Baeyens L, Bonné S, German MS, Ravassard P, Heimberg H, Bouwens L et al. Ngn3 expression during postnatal in vitro beta cell neogenesis induced by the JAK/STAT pathway. Cell Death Differ 2006; 13: 1892-1899.

15. Jacquemin P, Durviaux SM, Jensen J, Godfraind C, Gradwohl GGuillemot F et al. Transcription factor hepatocyte nuclear factor 6 regulates pancreatic endocrine cel differentiation and controls expression of the proendocrine gene ngn3. Mol Cell Biol 2000; 20: $4445-4454$.

16. Kroon E, Martinson LA, Kadoya K, Bang AG, Kelly OG, Eliazer S et al. Pancreatic endoderm derived from human embryonic stem cells generates glucose-responsive insulin-secreting cells in vivo. Nat Biotechnol 2008; 26: 443-452.

17. Artner I, Hang Y, Mazur M, Yamamoto T, Guo M, Lindner $J$ et al. MafA and MafB regulate genes critical to beta-cells in a unique temporal manner. Diabetes 2010; 59 : 2530-2539.

18. Raum JC, Hunter CS, Artner I, Henderson E, Guo M, Elghazi L et al. Islet beta-cell-specific MafA transcription requires the $5^{\prime}$-flanking conserved region 3 control domain. Mol Cell Biol 2010; 30: 4234-4244

19. Bonner-Weir S, Taneja M, Weir GC, Tatarkiewicz K, Song KH, Sharma A et al. In vitro cultivation of human islets from expanded ductal tissue. Proc Natl Acad Sci USA 2000; 97 7999-8004.

20. Boretti MI, Gooch KJ. Effect of extracellular matrix and 3D morphogenesis on islet hormone gene expression by Ngn3-infected mouse pancreatic ductal epithelial cells. Tissue Eng Part A 2008; 14: 1927-1937.

21. Streuli C. Extracellular matrix remodelling and cellular differentiation. Curr Opin Cell Biol 1999; 11: 634-640.

22. Rooman I, De Medts N, Baeyens L, Lardon J, De Breuck S, Heimberg H et al. Expression of the Notch signaling pathway and effect on exocrine cell proliferation in adult rat pancreas. Am J Pathol 2006; 169: 1206-1214.
24. Minami K, Okuno M, Miyawaki K, Okumachi A, Ishizaki K, Oyama K et al. Lineage tracing and characterization of insulin-secreting cells generated from adult pancreatic acinar cells. Proc Natl Acad Sci USA 2005; 102: 15116-15121.

25. Zhou J, Kherani F, Bardakjian TM, Katowitz J, Hughes N, Schimmenti LA et al. Identification of novel mutations and sequence variants in the SOX2 and $\mathrm{CHX} 10$ genes in patients with anophthalmia/microphthalmia. Mol Vis 2008; 14: 583-592.

26. Baeyens L, Lemper M, Leuckx G, De Groef S, Bonfanti P, Stangé G et al. Transient cytokine treatment induces acinar cell reprogramming and regenerates functional beta cell mass in diabetic mice. Nat Biotechnol 2014; 32: 76-83.

27. Gradwohl G, Dierich A, LeMeur M, Guillemot F. Neurogenin3 is required for the development of the four endocrine cell lineages of the pancreas. Proc Natl Acad Sci USA 2000; 97: 1607-1611.

28. Gu G, Dubauskaite J, Melton DA. Direct evidence for the pancreatic lineage: NGN3+ cells are islet progenitors and are distinct from duct progenitors. Development 2002; 129: 2447-2457.

29. Schwitzgebel VM, Scheel DW, Conners JR, Kalamaras J, Lee JE, Anderson DJ et al. Expression of neurogenin3 reveals an islet cell precursor population in the pancreas. Development 2000; 127: 3533-3542.

30. Pinho AV, Rooman I, Reichert M, De Medts N, Bouwens L, Rustgi AK et al. Adult pancreatic acinar cells dedifferentiate to an embryonic progenitor phenotype with concomitant activation of a senescence programme that is present in chronic pancreatitis. Gut 2011; 60: 958-966.

31. Rescan C, Le Bras S, Lefebvre VH, Frandsen U, Klein T, Foschi M et al. EGF-induced proliferation of adult human pancreatic duct cells is mediated by the MEK/ERK cascade. Lab Invest 2005; 85: 65-74.

32. Lefebvre VH, Otonkoski T, Ustinov J, Huotari MA, Pipeleers DG, Bouwens L et al. Culture of adult human islet preparations with hepatocyte growth factor and $804 \mathrm{G}$ matrix is mitogenic for duct cells but not for beta-cells. Diabetes 1998; 47: 134-137.

33. Lima MJ, Muir KR, Docherty HM, Drummond R, McGowan NW, Forbes S et al. Suppression of Epithelial to mesenchymal transitioning (EMT) enhances ex vivo reprogramming of human exocrine pancreatic tissue towards functional insulin producing beta-like cells. Diabetes 2013; 62: 2821-2833.

34. Zhou Q, Brown J, Kanarek A, Rajagopal J, Melton DA. In vivo reprogramming of adult pancreatic exocrine cells to beta-cells. Nature 2008; 455: 627-632.

35. Heremans $Y$, Van De Casteele M, in't Veld P, Gradwohl G, Serup P, Madsen $O$ et al. Recapitulation of embryonic neuroendocrine differentiation in adult human pancreatic duct cells expressing neurogenin 3. J Cell Biol 2002; 159: 303-312.

36. Bouwens L, Wang RN, De Blay E, Pipeleers DG, Kloppel G. Cytokeratins as markers of ductal cell differentiation and islet neogenesis in the neonatal rat pancreas. Diabetes 1994; 43: $1279-1283$

37. Feroze-Merzoug F, Berquin IM, Dey J, Chen YQ. Peptidylprolyl isomerase A (PPIA) as a preferred internal control over GAPDH and beta-actin in quantitative RNA analyses. Biotechniques 2002; 32: 776-778, 780, 782.

38. Bromberg JF, Wrzeszczynska MH, Devgan G, Zhao Y, Pestell RG, Albanese C et al. Stat3 as an oncogene. Cell 1999; 98: 295-303.

39. Robinson MJ, Stippec SA, Goldsmith E, White MA, Cobb MH. A constitutively active and nuclear form of the MAP kinase ERK2 is sufficient for neurite outgrowth and cell transformation. Curr Biol 1998; 8: 1141-1150.

(c) (1) $\circledast(-)$ This work is licensed under a Creative Commons Attribution-NonCommercial-NoDerivs 3.0 Unported License. The images or other third party material in this article are included in the article's Creative Commons license, unless indicated otherwise in the credit line; if the material is not included under the Creative Commons license, users will need to obtain permission from the license holder to reproduce the material. To view a copy of this license, visit http://creativecommons.org/licenses/by-nc-nd/3.0/ 